\title{
Model, Methodology, and Forecast: Expert Data in Assessing Political Risk in Malaysia
}

\author{
Llewellyn D. Howell \\ Thunderbird School of Global Management at ASU, Glendale, AZ, USA
}

\begin{abstract}
This study is about Malaysia's investment environment. I've undertaken its writing in part as a reflection on my own involvement with Malaysia over more than half a century (from Malaya in 1963). The study also brings to bear a structure for analysis drawn from the field of political risk analysis. I have been involved with formal (corporate) political risk assessment since 1979 and bring that experience into the discussion that follows. I have published extensively on both Malaysia and political risk. Some of these publications are cited below. Political risk assessment depends on experts on the countries that they examine. I don't usually refer to myself as an "expert" but rather as a specialist. However, the common reference in political risk studies is to data generated by experts. In the paper below I discuss the nature of political risk assessment, Malaysia, my own credentials that have gotten me into the political risk business, and three political risk assessment methodologies, with the results for Malaysia for each. I give emphasis to the assessment that I have done using the Economist method, for reasons that I provide below. I was able to incorporate interviews of 35 professional subjects in Malaysia in February 2014 in which they were each able to rate Malaysia using the Economist method. They were drawn from government, business, journalism, and academe. I think the results are interesting, at least.
\end{abstract}

Keywords: Malaysia, political risk, expert data, Islam, politics, race, ethnicity

\section{Political Risk: What is it and How is it Done?}

Political risk involves asking country experts or specialists to describe a country's political environment as it is defined in one of several well-vetted models used to project risk, mainly for business management and insurance purposes. Virtually all of the models rely on theories that have been composed in the academic world and their data come from human input derived from their knowledge and experience, then converted into systematic entries (i.e., quantitative data) that are then translated into numerical forecasts. Political risk analysis is not just a description of specified current conditions, as many see it. It is, instead, a forecast-a projection - of what those conditions will be - individually and in combination - one year or 18 months or five years from now. If there is any profession like that of a political risk analyst, it is that of a meteorologist. We project the political weather conditions and advise the user on whether to take an umbrella or not when they go out the next day. It's not about whether it is raining now; it is about whether it will rain tomorrow. It's a tough task in either field. It's about probabilities, not predictions.

I, among many others, provide the human input that ultimately becomes a rating for a country like Malaysia, like a BBB, or B-, or a 67 out of 100. These ratings are considered by investors looking at Malaysia 
or some other country (including the US) to determine what they should be willing to pay as interest on loans, what kind of risk insurance they should buy, or how they should physically protect themselves. You may not like this (and many don't) but this is the way it works.

What I am attempting to do in this chapter is to show what this looks like from the bottom up. That is, to create a country rating, someone does an assessment on a scale and enters a figure that ultimately gets translated into a country rating, a loan interest rate, an insurance selection and cost, or the hiring of a private security contractor. Here is where it starts, although the buck doesn't simply stop here.

In Figure 1, the two photos portray how a country can be seen by a promoter of the country's investment opportunities (car on the left) and how it is seen by a political risk analyst (on the right). A promoter presents the ideal. The analyst takes it apart and examines it piece by piece. Taking a country apart, piece by piece, and examining it is the task of a political risk analyst.

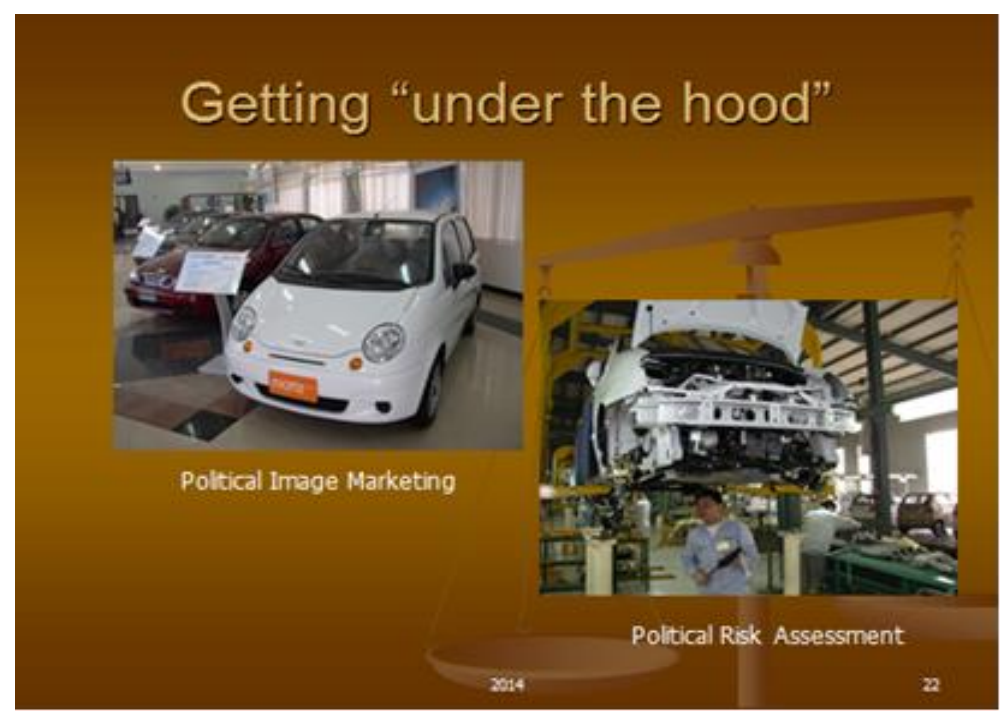

Figure 1. Getting under the hood.

The "what is it?" question about political risk has been asked and answered dozens or hundreds of times in the literature over the last 40 or 50 years. Since 1979, when the US Embassy in Tehran was suddenly overwhelmed in a flash revolution that surprised everyone, perhaps even Iranians themselves, scholars, politicians, business people, and analysts have been asking the question "Why didn't we see this coming?" A few did. In 1965, just to cite one case, the US Congress authorized the formation of the Overseas Private Investment Corporation (OPIC), a government-owned corporation that provides insurance and investment support to American companies venturing into unsettled international markets. In its insurance coverage, OPIC provides policies for: (1) Confiscation, expropriation, and nationalization coverage; (2) Contract repudiation coverage, providing coverage for noncompliance with contracts by the foreign government; (3) Inconvertibility of currency coverage; (4) Civil war, including religious, tribal, and cultural wars. And international war. Acts of terrorism were built in as a part of the conflict environment (Johnston \& Howell, 2013).

Almost all of these categories would have covered the numerous losses that occurred 14 years later in Iran but few American companies had purchased this political risk insurance or any other. Why not? Primarily because few political risk forecasting companies were in existence at the time and that those were ignored by US companies rushing into lucrative foreign markets. 
Political risk assessment and analysis blossomed after the Iranian revolution but was solidly in place shortly after OPIC presented political risk insurance as a US government-sanctioned enterprise in the mid-1960s. But the field came of age quickly after 1979, not only with academic analyses and publications but with businesses being established that conducted analyses for a fee.

\section{A Definition}

Political risk is the probability (a forecast, not a prediction) that some political factor like an ethnic dispute, a popular response to government repression, or a government decision on control of private enterprise, will result in a loss of some kind to a foreign enterprise operating in a country. The enterprise might be Japanese operating in Botswana or Malaysian operating in the United States. Particularly important, this is not just about developed country businesses investing in less developed countries. Every country has foreign investment and, therefore, every country has political risk. The US has plenty for foreign investors there.

The term political risk refers to the possibility that political decisions or political or social events in a country will affect the business climate in such a way that investors will lose money or not make as much money as they expected when the investment was made.

Country risk, on a larger scale, encompasses political risk by incorporating economic and financial characteristics of a system, along with the political and social, in the same effort to forecast situations in which foreign investors will find problems in specific national environments.

Country risk is a composite of other indices and assessments, one of which is political risk. Country risk is a larger entity but political risk resides within the control of the investor. Sovereign risk is yet a smaller component of political risk, focusing on direct government action vis-à-vis the company. Within country risk, political risk is generally given the most importance by analysts for a variety of reasons. Political risk is given primacy because it is insurable against most forms of political risk losses, with the exception of corruption.

Political risk assessment falls within the purview of a foreign investor's practice of due diligence. Assessment refers to a measure, in this case a probability measure, which acts as a warning of the level of threat. In political risk analysis, the origins or causes of the threat-whatever its level-are the object of attention. There is, therefore, an important difference between the terms assessment and analysis, although they are often used-mistakenly - interchangeably. Assessment is a response to the question "what?" while "analysis" responds to the question "why?".

Another version of the difference is expressed by Jan Goldman of the Joint Military Intelligence College (JMIC) who refers to assessment as a "warning product" and to analysis as "conclusions based on the combination of assessments and their interaction" (Goldman, 2006a; 2006b). Others have referred to the difference between the two terms as the distinction between what you "know" and what you "believe". In any case, the difference amounts to what is being provided as a picture in the former case - the warning - and to what is being produced as explanatory theory - the conclusions - in the latter. This is an important difference in products.

Some approaches to political risk assessment describe this as being an effort to project or forecast harm to the investor by political and social forces in the host country or resulting from political decisions. Again we find that the terms assessment and analysis are used interchangeably for both country and political risk, although they actually have different (although related) objectives.

For international management, the immediate managerial need is for assessment. But the more important 
goal is analysis since it is through determination of causes of future behavior that the right assessment can be made and the right management tools can be brought to bear. In the discussion below, the emphasis is on the term analysis and the goal of useful theory in trying to shape our knowledge of the political risk field for productive use by managers.

In many approaches to risk assessment, political risk is subsumed in country risk ${ }^{1}$. However, there is a need to report political risk separately. First, there is an availability of political risk insurance. As will be discussed below, this insurance covers losses that are due to political acts only, not to economic or financial conditions or circumstances. Therefore, a country risk rating that includes these other aspects of general risk will not be useful guidance as to the need for political risk insurance or to the level of premium that an investor should be willing to pay. Second, the tools for managing political risk are very different from those that would be employed in managing economic or financial risk. A country risk rating, which incorporates a variety of characteristics of the investment situation, is not good guidance for a manager trying to deal with specific political or social elements in the investment environment. It is therefore important to deal with country risk and political risk separately even though many theories and methods combine them.

In focusing on political risk analysis, it is useful to construct a definition of what counts as political by beginning with political risk coverage for insurance. Insurance from OPIC and the Multilateral Investment Guarantee Agency (MIGA) of the World Bank is characteristic as well as prominent in considerations of insurance availability (O'Connell, 1997). Both OPIC and MIGA cover four major types of losses to investors that are typical of the harm that can come from the political and social environments in which they operate. These major types of losses (as distinct from types of insurance), plus six other significant types, are as follows:

(1) Inconvertibility, action taken by a government to prevent conversion of local currency to some form of foreign exchange such as dollars. In recent years, due to expanded agreements, regulation, and market forces, this form of political risk insurance has been in little demand; (2) Expropriation or Nationalization, an action taken by a government to seize property or assets of the foreign investor without full compensation to the foreign investor; (3) War Damage, losses resulting from an international conflict; (4) Civil Strife Damage, losses generated by internal conflict; (5) Terrorism Damage, losses due to acts of terrorism; (6) Contract Repudiation. Also known as "contract frustration" or "breach of contract", this loss results from government termination of contracts without compensation for existing investment in the project or service; (7) Sea Piracy Losses. A long standing form of loss, with insurance coverage dating to 1799 from Lloyd's of London. Although long abandoned to the realm of film and stage fantasy in Peter Pan and Pirates of the Caribbean, pirates have continued to be major threats to sea going business. Pirate attacks on sea going vessels have continued after a great surge in the aftermath of the Vietnam War. Many are simple robberies but they have increasingly included the murder of crews, theft of cargo - including oil, the kidnapping of personnel, and even the theft of ships. The taking and disappearance of the oil tanker Petro Ranger in 1998 drew considerable attention but it wasn't until a pirate attack on the cruise ship Seaborne Spirit off the coast of Somalia in late 2005 that security attention shifted to this critical aspect of international business. Now attention has refocused on piracy problems, not only for the cruise and tourist industries but also for the potential impact on sea lines of communication, especially the Strait of Malacca through which $90 \%$ of East Asia's oil passes. Given the

\footnotetext{
${ }^{1}$ See the description of the country risk method provided by Standard and Poors, for example, where political risk composes a part of the calculation of country risk ratings but it is the country risk rating that is reported on an AAA to D scale. Political risk is not reported separately.
} 
potential for exploitation by Islamic terrorists, management of the piracy problem — rather than insurance - has become an important aspect of political risk assessment (Howell, 2006; Luft \& Korin, 2004; Langewiesche, 2005; Howell, 2013).

Three more broad categories complete the range of losses that stem from political sources. Probably the most common source of losses to foreign businesses is from:

(8) Negative Government Actions. Governments often formally decide to reduce or restrict earnings or participation of foreign investors in ways that are less direct than expropriation or inconvertibility. Ordinarily, losses that result are not covered by insurance, although almost anything can be insured through private insurers. Political Risk Services (PRS) includes the following among their list of possible sources of loss that fit in this category (PRS Group, 2004). ${ }^{2}$ Equity Restrictions would be a government decision or a decision by a segment of the government, such as a ministry. Personnel/Procurement Interference occurs in many political systems. Taxation Discrimination directed at particular companies or particular nationalities is the result of a decision of someone in government and may reflect social issues or prejudices. Repatriation Restrictions, Exchange Controls, Tariff Imposition, Non-Tariff Barrier Imposition, and Fiscal/Monetary Expansion, all of which may affect businesses negatively, are the result of government decisions. Labor Cost Expansion, Payment Delays and Bureaucratic Sluggishness may be functions of government policy or simply government inefficiency, but all are affected by government decisions at some level in the system.

(9) Process Deterioration includes those losses to businesses that result from indirect government action, government attributes (rather than decisions), and societal processes or characteristics. Examples of these, respectively, are lack of enforcement of copyright agreements (where the government may be simply incapable of enforcement), government interference in operations (such as with racial quotas in hiring of managers), and bribery and systemic corruption (where American investors need to be sensitive to the application of the Foreign Corrupt Practices Act).

(10) Event Intervention. This loss results from some event that is political in its nature or source, while not being a result of a known government decision or indecision. Examples of event interventions that affect businesses negatively would be kidnapping of managers or executives (with "Kidnapping and Ransom" insurance coverage), strikes or production stoppages that occur with political rather than economic or financial objectives, and sabotage or damage to a plant or service that originates with a political or religious group in the host country (sometimes covered under "Civil Strife Damage").

Political risk analysis is directed at locating the sources of risk and determining assessment, projecting the probability of these ten types of losses, and thus acting as advisement to investors regarding both choices about management tools and insurance.

Also important to reiterate, political risk is not solely about government decisions as some analysts continue to insist. It is part and parcel of societies and the contexts within which they are governed. Decisions that governments make, or actions that they take that affect foreign investment and the country's financial and economic environment, are called sovereign risk.

Political risk refers to threats within sovereign entities (a country with borders) but those threats may emanate from within or without. For example, when country $\mathrm{X}$ is under threat of invasion by its neighbor country $\mathrm{Y}$, that is a threat to operations of businesses within its borders, even though conditions within the host

\footnotetext{
${ }^{2}$ Retrieved from http://www.PRSgroup.com (click on “About Us”, “Our Two Methodologies”).
} 
country itself are wonderful. Almost all political risk indices include some recognition of external threats.

Importantly, a factor that distinguishes political risk from country risk is that the elements in political risk can be defended or offset by the investor while those that extend political risk into country risk cannot. For example, religious tensions or ethnic tensions that lead to conflict resulting in the death of workers or an interruption in production can be insured against (e.g. with MIGA or OPIC) or the facility can be protected by a private security contractor, while foreign debt and exchange rate stability are beyond the reach of a foreign investor. There is little they can do directly about the foreign debt of the host country.

Political and country risk ratings are important to businesses and investors as a part of managing their risk and maintaining profitability. They are also extremely important to governments because they describe the investment climate in the country and will encourage or discourage incoming foreign investment. Every government is concerned about their ratings, including the United States.

The ratings are, of course, not a measure of any of these losses, even in the past. Political risk ratings are, instead, quantified assessments of what are regarded as the precursors of the losses. Racial conflicts (such as verbal), or even racial divisions, are, for example, precursors of fighting among the race-identified parties, or grounds for hiring or not hiring employees for certain types of work within the investor's industry. Corruption may be a charge on the investors' bottom line that prevents them attaining profitability or may be an indicator of potential seizure or even arrest of the investor.

\section{Human Intelligence}

Political risk assessment is accomplished by having country experts take their knowledge, experience, and specialization and make observations on conditions in the country that relate to long-term business success by foreign investors. I want to stress that this is not just opinion. Intelligence agencies asked for similar assessments from their agents in the field, and go so far as to evaluate the source and the information itself on a six-point scale in order to ultimately determine its value. In political risk assessment, the sources are not rated but instead are assumed to be "expert" by virtue of having been hired by the company doing the rating. But the process is the same. The measurements are not based on the number of dollars exchanged nor the tonnage of cargo nor the sometimes arbitrary measurement of what is bought and sold. There is little hard data for political risk assessment. We need human observation. For a person who is hospitalized, doctors or nurses will come in each day and assess the patient's pain on a scale of five or 10 points. This is done daily to determine whether the patient is improving or not. On the basis of what the patient says (the expert), doctors write prescriptions and propose treatment. If a patient response to their question by indicating that she is "eight" in pain, the doctor does not respond by saying "oh, that's just your opinion". That number becomes hard data. So it is in political risk assessment.

Just like we have multiple indicators for a patient's health (pain assessment, body temperature, oxygen level, pulse, blood pressure, and others), we have indicators in political risk that assess the country's political health. These vary but also have some commonalities that will be discussed below. The choice of variables has to do with the theory that a model's originator brings to the assessment and analysis. In this study of Malaysia, three of these models, with their choices of variables, are presented. The Economist model is the focus in this discussion.

Important: It is always important to keep in mind that the purpose of political risk analysis not to get a rating for a country, even though that is the product most widely disseminated. The purpose is to advise 
investors. This is why the forecasts are critical and this is why every variable in a model is important to the investor, not just the country's overall rating. That rating isn't particularly meaningful (as in ICRG's case) if the investor doesn't know what to do with it. That is, the country's rating doesn't indicate whether the risk arises from sectarian conflicts that could turn into civil war damage (hence suggesting civil strife insurance) or from corruption that suggests avoiding investing in the country (since there's no insurance against bribery needed to get a contract). And it's up to the analyst to make these connections as the country expert, not the customer. A country rating without risk sourcing may be interesting but not very useful.

\section{Next, What is Malaysia?}

Malaysia is a resource and skills rich tropical paradise located in the heart of Southeast Asia. Founded as "Malaya" in 1957, with independence from Great Britain, Malaysia was born in 1963 with the addition of other former British colonies Singapore, North Borneo (now known as Sabah), and Sarawak. In 1965, Singapore was asked to leave the federation when the controlling party in the country, the United Malays National Organization (UMNO), determined that the racial balance was such that the Chinese minority was close to taking over a ruling position in the new country. Its entire political history since 1963, now more than half a century, has been built around this one issue of racial balance, starting and ending with UMNO being the controlling power. It is about Muslim Malays ruling the country, racial separation reinforced by religion.

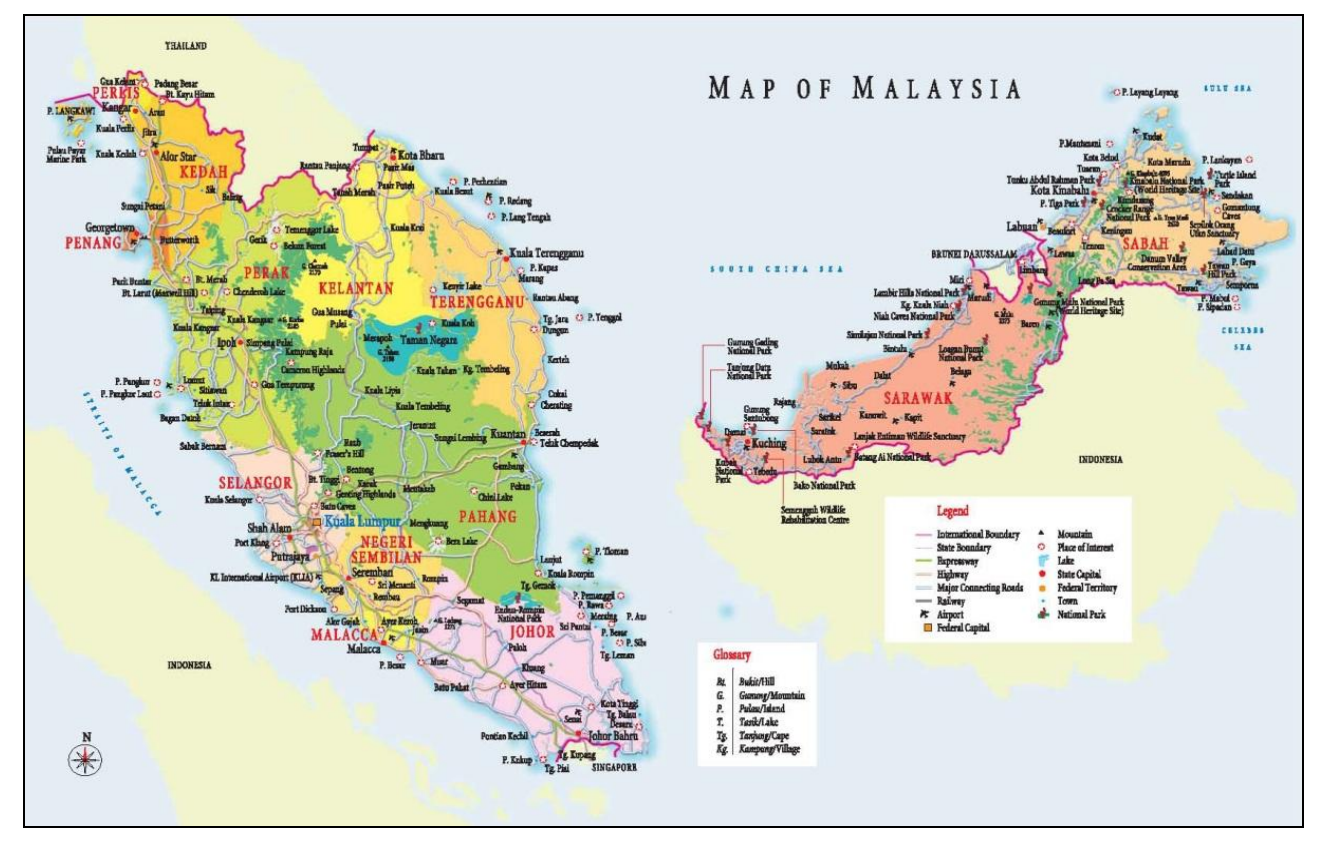

Figure 2. Subdivisions of Malaysia.

Malaysia is a democratic country in most respects, except when the Chinese get close to election victories. In 1969, in one such case, early returns indicating a likely Chinese takeover of the government led to premature Chinese celebrations and a violent Malay response. Fighting and rioting in Kuala Lumpur, Malays with parangs (machetes) and Chinese with sections of pipe and other weapons of convenience, resulted in somewhere between 200 and 2000 deaths and more injuries. The army (almost all Malays) intervened to stop the killing.

The UMNO-led government suspended the constitution for two years while economic complaints from Malays were addressed. The Chinese, while only about $35 \%-40 \%$ of the population, were in control of 
two-thirds of the economy, foreigners controlling a significant proportion of the rest, Indians and other non-Malays another portion, Malays only about four per cent. The figures were imprecise because much of corporate and land-holding ownership was through third parties (Malays) and did not reflect actual control.

A "National Economic Policy (NEP)" was put in place for a 20-year period to assist Malays in entering the economic marketplace. It granted Malay privileges in the holding of franchises in such areas as logging, shipping, and taxi companies, gave fixed minimums in seats at state universities (most of them), required investing companies to provide fixed minimum percentages of positions in private sector companies to Malays, and special education privileges for Malays, both domestically and internationally. At one time in the 1980s, Malaysian students (mostly government sponsored Malays) were the largest foreign student contingent in the United States, more than 50,000.

Over the 20 years of the NEP, Malays were able to add conspicuously to their economic holdings. But the Chinese and Indian Malaysians added more, both of their totals coming out of foreign investment, which dropped significantly as domestic enterprise was encouraged, by government support for Malays and non-Malays added industry and enthusiasm to build their share. The Chinese and Indians, nevertheless, saw the singular support for Malay education and investment as prejudicial and patently unfair. As the NEP reached its 20-year expiration date, without Malay objectives having been met (still not industrious enough, many said), the government scrambled to find ways to continue it. It did this with the introduction of the National Development Policy (NDP) in 1991 which continued most of the same preferential treatment policies as the NEP. The NEP and the NDP have been the source continuing antagonism between Malays and the other half of the population, citing its favoritism, its division of the country into two nearly equal halves, and the corruption it has bred, especially in the business sector.

This tenuous racial balance has continued, its origins deep in peninsular and island history. There are indications that Chinese and Indian outposts were put in place as early as the First Century, before the modern notion of "government" or "country" was even operative and before the governance structure contained in Islam was introduced.

The Malay population of the region is thought to have migrated from southern China several thousand years ago, supplanting an aboriginal group known today as the orang asli. The early Malays were Buddhists and Hindus, religions introduced from India. Traders from India and the Middle East introduced Islam in the later part of the Ninth Century. ${ }^{3}$ The consolidation of the Malay race and Islam, and the structuring of Malays organizationally into sultanates, brought about what remains as political governance in Malaya (Sarawak, Sabah, and Penang do not have sultans). One of the eleven state-level sultans presides as the king or "Agong" (officially the "yang di-pertuan Agong"), elected from among themselves and by themselves every five years. And, again officially, non-Muslims are excluded from this ruling hierarchy. It is more than I can cover in any reasonable detail here, but Malaysia's constitutions, promulgated under British rule, are bifurcated, with a broader structure applying to everyone and a more narrowed set of strictures that apply to only Malays, who in turn are defined as Malay Muslims.

It's a complex history, worthy of the hundreds (maybe thousands) of books that have addressed it. Race is the main character in this play of all of politics and most of economy. Certainly, social relations are dependent on race. Malaysia's relations with its powerful economic and military-minded neighbor (for its own protection)

\footnotetext{
${ }^{3}$ Islam in Malaysia. Islam Can. Retrieved from http://www.islamcan.com/islamic-history/islam-in-malaysia.shtml
} 
Singapore revolve around race.

Every country is like the elephant assessed by three blind men. It "looks" very different depending on whether one is holding the trunk, a leg, or the tail. Malaysia is like a national elephant, both for those inside the country and those outside. In this study, I'm looking at the country from the outside, the perspective of a potential investor. The problems engendered for foreign investors are referred to as "political risk". Political risk is a calculation based on a model of sources of trouble for foreign-owned businesses and foreign financial investors planning on entering the country's markets. ${ }^{4}$

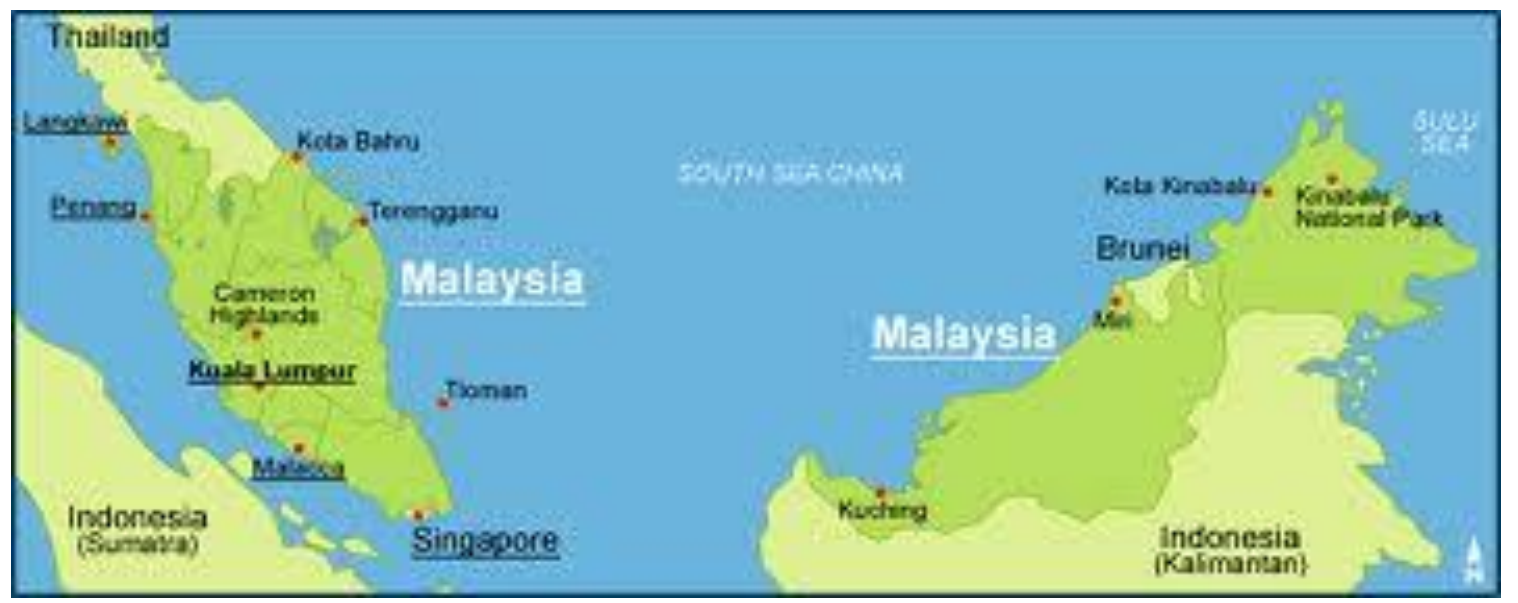

Figure 3. Malaysia Divided by the South China Sea.

I'll set aside the notion of even-handedness for a moment that most models of political risk try to assert. I'm going to start with Malaysia and work backward to its political risk levels. The study is an advisory on Malaysia, rather than a comparative analysis that might lead an investor to another target for investment, although it can be converted without much trouble.

To jump to the larger picture to start, Malaysia (2013) is a country of more than 28 million citizens. Ethnic Malays make up a bare majority of the population of Malaysia at $50.4 \%$. Another $11 \%$ are defined as "indigenous" peoples of Malaysia or bumiputra, literally "sons of the earth". Ethnic Chinese make up 23.7\% of Malaysia's population, while $7.1 \%$ are ethnically Indian, and $7.8 \%$ are from other ethno-linguistic groups. ${ }^{5}$ Malaysia's risk story begins with disagreements about these numbers.

Kallie Szczepanski, a contributor to the online "Asian History", provides numbers, cited above, that are typical of those presented by sources without a stake in the game on Malaysia. Those with a stake in the country, specifically the Malay-run government itself, characterize it differently. Others have noted the difficulty in getting straight numbers out of the Malaysian government, especially on issues having to do with race. $^{6}$ Szczepanski and others cite a figure of around $51 \%$ as Muslims, for example (all the Malays plus some Indian Muslims) while the government releases figures around $60 \%$.

Malaysia is a state divided in many ways. It's divided and multifaceted. Its multidimensionality is its attraction but is also is its worrying threat. It's a compelling and contradictory story. This is a story about race.

\footnotetext{
${ }^{4}$ See the November, 1986 Economist article "Countries in Trouble" as the introduction to the notion of "trouble" for foreign investors.

${ }_{6}^{5}$ Kallie Szczepanski. Asian History. Retrieved from http://asianhistory.about.com/od/malaysia/p/malaysiaprof.htm

${ }^{6}$ Critics have recently noted what they call "an obfuscation of crime statistics" in the midst of a crackdown on crime in Kuala Lumpur (Fuller, 2013).
} 
Over its entire modern history, race relations have been the dominant theme in Malaysia's politics, social development, and economic development. None of these can be understood without beginning with the issue of race and its ancillary cultural theme of religion. Law, political parties, business development, and foreign relations, among other issues, all are composed around the matter of race.

Race therefore has to be first among equals in any systematic or personalistic assessment of the environment for any analysis, certainly that for foreign investment. It will have a special place in this essay about political risk for investors in Malaysia.

This essay is a little different than most you will find on political risk, including the many that I have written. I am writing here from one analyst's perspective, both on Malaysia and on political risk. Regarding the latter, all political risk assessments are dependent on one or more country specialists quantifying their judgments and then explaining what they gave the scores they did. Some risk firms have several analysts provide scores for a country and then combine them in some way (like an average of three scores), while at the other end of the scale there may be only one analyst for a region. Editors play a big part and may or may not go along with the country specialist and may assign their own score.

Regarding Malaysia, I have my own identification with Malaysia and my own history, as I will note below. I have done political risk assessments for several different firms, on Malaysia, Singapore, and Brunei. I have lived in both Malaysia and Singapore and have a "feel" for these countries. I read about them both carefully and keep up with events and other commentaries. Still, mine is one view. You will find that reflected here and you should judge it on the basis of what I bring to the table, compared to others.

My interest in race and race relations began not in the US but in a small Malaysian village in 1964 where I was serving as a Peace Corps Volunteer, teaching in the village school. I lived in a small cement house with the school's Islam teacher and the school janitor, also a Malay Muslim. The school's population was almost evenly divided among Malay Muslims, Chinese, and Indians. The three groups of students got along well and, superficially at least, race was not an issue among them. Outside of the school, however, race was treated differently. The divisions among the groups were deep. How, I asked, did it get to be so? Was there likely to be any resolution to the problems that constantly arose there and in other societies that I could see around me in Southeast Asia?

I returned to the US to graduate school with the intent of examining this problem in Malaysia and elsewhere. This was, of course, right at the height of the civil rights movement in the US. There was plenty to examine at home. I did. In 1969, however, major rioting and numerous deaths occurred in Malaysia, with fighting between Malays and Chinese. On May 13 and in the weeks thereafter, somewhere between 196 (the official count) and a reported 2,000 people were killed in street fighting and other incidents. Racial conflict was rife in the US at the same time. Both matters spurred my interest.

I began that year to lay out a Ph.D. dissertation proposal that resulted in a five-country (Malaysia, Singapore, Indonesia, Thailand, and the Philippines) survey on racial and ethnic ${ }^{7}$ prejudice in Southeast Asia with more than 2,400 respondents in 1970-1971 (Howell, 1973). In conjunction with this work, I conducted a race study in Hawaii, looking at racial attitudes in Hawaii's diverse population (Howell, 1977). I followed with another Southeast Asian survey (Malaysia, Thailand, and the Philippines) in 1981-1982, roughly ten years after the first (Howell, Carlos, Thumrongvit, \& Bock, 1984). In 1987-1988, during a Fulbright year in

\footnotetext{
${ }^{7}$ It is important from the onset to be sure that we understand that race and ethnicity are not the same thing. Race involves physiological characteristics while ethnicity adds culture, history, and community to the mix.
} 
Malaysia, I had an opportunity to survey Malaysian civil servants with the same questionnaire I had used in the earlier two surveys and to make some comparisons across the period 1970-1988 (Howell, 1990).

I have continued my interest and analysis of race questions for Southeast Asia and in the US over the last several decades. It includes today, clearly, not just questions of black and white or Malay and Chinese but also the entire range of color identities that are infused in immigration and conflict questions around the globe. I have periodically written about the question (Howell, 1993; Howell \& Palmer, 1995; Howell, 2002; Howell, 2006; Howell, 2010; Howell, 2011) and have given numerous talks on the issue of race, in addition to talking to my students at Thunderbird School of Global Management, The American University, and the University of Hawaii. I regard race relations - and the issue of race itself - to be the most critical and most intriguing of the questions before us in sociology and politics.

\section{The Making of a Country Specialist}

The way that I learned the story of race in Malaysia has something to do with the way I analyze its social, political, and business environment, in any kind of setting —including academic. For a country specialist (and I stay away from the use of the term "expert"), one's perspective depends at least in part on how knowledge was obtained, what allegiances have been forged, and identities that have been built in over years of experience. "Where you stand depends on where you sit", so to speak.

I began my experience with Malaya, as it was called then, in Dekalb, Illinois, in February 1963 where I received my training before journeying on to my Peace Corps assignment as a secondary school teacher. The immersion in Malaya studies included Malay language training, which was filled with cultural examination as is the case with any language study. The Malay language courses were taught by Malays who were brought from Malaya specifically to teach us. This was my first contact with anyone, ever, from Malaya. It was an over the edge experience. We all studied them as much as anything from our books or instruction in Malay. It turned out that they had prepared us well, whether they did it knowingly or not.

In May, 1963 a group of 60 of us traveled on to Malaya and almost immediately out to our assignments. In that first year I was assigned to a high school in Province Wellesley, near Penang, to teach chemistry, physics, and biology. It was from there that I witnessed the birth of the new country, Malaysia. I was filling out an assignment that another Volunteer was vacating and his replacement came along at the beginning of 1964, so I was offered an assignment of my choosing for the second year. I chose to go to a kampong (village) school in Negeri Sembilan, a state in the south, near Malacca, where I taught high school math and three subjects in Standard Five, the fifth grade.

I can't imagine what would have been a more fruitful or impactful year. With my housemates (the school's Islam teacher and the school's janitor, both Malays who spoke no English) and off the school grounds, I had to use Malay, now the National Language (Bahasa Kebangsaan). I studied Malay several nights a week in the school's evening classes with Chinese and Indians from the village. I played basketball as the center on Linggi's town team (all Chinese) and toured throughout Negri Sembilan and Malacca to play opposing town teams and in tournaments. My students here were split almost evenly between Malays, Chinese, and Indians and I had many opportunities to visit with their families and to become as steeped in these cultures as an American can be.

At the end of my Peace Corps tour in 1965, I changed career direction, from teaching science to becoming a country and regional specialist with a focus on Malaysia and Southeast Asia. After my two-year Peace Corps 
assignment, I went into graduate school in International Relations. I had an internship and brief appointment at the State Department in Intelligence, for Southeast Asia, at the height of the Vietnam War (1966). I spent a semester at the University of Hawaii Peace Corps Training Center preparing more Peace Corps Volunteers for service in Malaysia.

During my Ph.D. work at Syracuse University's Maxwell School, I specialized in International Relations in the School's Political Science Department and took a field in Southeast Asia at Cornell University. At Cornell I worked with renowned political science professor George McT. Kahin, ${ }^{8}$ Indonesia historian Oliver W. Wolters (1999), and former Ambassador to Indonesia and Japan John M. Allison (Allison, 1973). My primary professor there and member of my Ph.D. committee was historian David K. Wyatt, a specialist in the Thai royal family. At Syracuse I worked extensively with Oliver E. Clubb, Jr. (1962), a Southeast Asia expert who had focused, at the time, on the Vietnam War. My dissertation involved a sociometric examination of elite social and political attitudes in five Southeast Asian countries: the Philippines, Singapore, Malaysia, Indonesia, and Thailand, involving ground survey work in each of the original ASEAN countries. At the end of my field work in 1970-1971, based in Manila and then Singapore, I had about 2400 respondents on two sociometric instruments, in five languages, the respondents about evenly divided between the five countries (Howell, 1971; 1973a; 1973b; 1974).

I began teaching in the International Relations field in 1971, first at the University of Hawaii and then at American University's School of International Service. In 1981 I began training American diplomats and embassy personnel regarding Malaysia at the American Foreign Service Institute. During a sabbatical leave in 1981, I returned to Malaysia, the Philippines, and Thailand to read minister the same sociometric instruments that I had used in 1970-1971 in a "Ten Years Later" study.

I have periodically returned to Malaysia for visits and research projects. In 1987-1988 I was a Fulbright Scholar in Malaysia, assigned to the National Institute for Public Administration (INTAN) where I worked training Malaysia civil servants (diplomats, military officers, police), primarily in political risk assessment and management. I continued this on a consultant basis until the financial crisis in 1997. At that point I continued the same instruction in Singapore through 2002.

After 2002 I have made periodic visits back to Malaysia, while working in Vietnam for the University of Hawaii's Executive MBA program in Hanoi. I am at work on a book on Malaysia ${ }^{9}$ and keep in regular touch via ever-expanding internet access. ${ }^{10}$ In February 2014, I went to Malaysia specifically to interview Malaysians and foreign investors there about how they saw the political risk problem for Malaysia. I interviewed 35 individuals who were drawn from government, journalism, business faculty, and private sector businesses, domestic and foreign. To each I administered a political risk assessment scale, a ten point scale for ten variables, drawn from the Economist method described below. Their assessments are incorporated below. I also had a chance to talk to many others about domestic politics (especially the role of the king or Agong and the sultans and royalty) and the international context. Taxi drivers, for example, were particularly revealing in this regard. Then, Malaysia has been in the news in the US regularly since, with opposition party events and a Malaysia Airlines disappearance bringing it to the fore.

\footnotetext{
${ }^{8}$ George McT. Kahin, Southeast Asia: A Testament, Routledge Curzon, 2003; with John Lewis, The United States in Vietnam, 2nd edition, Dial Press, 1967, 1969, inter alia.

9 Race, culture, and foreign policy: A Malaysian case study. The Edwin Mellen Press, forthcoming.

${ }^{10}$ For example, there's the New Straits Times online.
} 
It has been a half-century since I first scrambled to find out where Malaya was in a handy encyclopedia when my Peace Corps invitation arrived in September of 1962. Now I think of myself as having been raised in Malaya and Malaysia (second time, of course). I didn't know much until I arrived there to smell the night air. After 50 years, I'm as comfortable in Malaysia as I am in the US. Both are extremely exciting and stimulating environments; both have their problems. In this chapter, I am writing about Malaysia's problems, without forgetting that this is a wonderful country, dynamic for some of the same reasons that it has drawbacks, and fruitful for the many businesses that have already migrated there. But what is the future? And what difference does it make what I think of that future?

\section{Alternative Theories}

Political risk has been modeled in different ways depending on the theory that underlays thinking about the relationship between society and government, on the one hand, and actions detrimental to foreign businesses on the other. The Business Environment Risk Intelligence (BERI) model is based on the theorizing by business professor F. Ted Haner. The International Country Risk Guide (ICRG) was constructed by the editors of international reports in 1980, a widely respected weekly newsletter on international finance and economics (McKee, 2013).

The International Country Risk Guide (ICRG) (McKee, 2013) divides country risk into three components. Fifty percent of Country Risk is Political Risk. Twenty-five percent is Economic Risk and 25\% is Financial Risk. As noted below, each of these is divided into sub-indices, weighted, and rated by country specialists. Rating Political Risk and Financial Risk takes different skills. Country Risk is the larger, combined overview.

The ICRG model was created in the 1980s and is a business that has progressed through several ownerships. It now resides with the PRS Group in East Syracuse, NY, USA. It is widely used and respected (McKee, 2013, p. 41). It provides a 100 point evaluation of a country's current and future political situation based on a 12 variable scale.

Government Stability 12 points and three sub-variables, Socioeconomic Conditions 12 points and three sub-variables, Investment Profile 12 points and three sub-variables, Internal Conflict 12 points and three sub-variables, External Conflict 12 points and three sub-variables, Corruption six points, Military in Politics six points, Religious Tensions six points, Law and Order six points, Ethnic Tensions six points, Democratic Accountability six points, Bureaucracy Quality six points. TOTAL $=100$ positive points (i.e a higher score is better).

The raw scores for Malaysia for January 2014, present analysis, are provided below in Figure 5. Each are given weights according to the theory that underlays the ICRG system. The first five are 12 points, the next six are six points, and the last is four points for a total of 100. In January of 2014, Malaysia's specialists gave it a total rating of 73. As a total, this compared with: Luxembourg 88, New Zealand 87.5, Norway 87.5, Sweden 87.5, Finland 86.5, Canada 85, Iceland 85, Germany 84.5, Australia 83, Singapore 83, United States 82, Poland at 74, Slovakia at 74, Malaysia 73, Oman at 72.5, Philippines 63, Thailand 57.5, Indonesia 55.5, Syria 40.5, Sudan 38, Congo 37, and Somalia 30.

Malaysia is clearly not in the basket case category with Sudan and Somalia but it is well behind its rival, Singapore. In the complete population of countries, Malaysia is above the middle of the rankings. It is better than its neighbors except for Singapore, but therein lays the story of Malaysia. See my Economist explanation below. 
Figure 5 shows the weighted scores for Malaysia for the 12 ICRG variables. Figure 6 shows more of interest to the investor in the standardized scores for the 12 variables. At the end of the scale showing the most threat are Corruption and Political Instability, followed by equal scores for Ethnic Tension, Religious Tension, Law and Order, and Democratic Accountability. If this were the forecast, it is here that foreign investors would look to guard themselves. To guard against corruption, the best solution is avoidance.

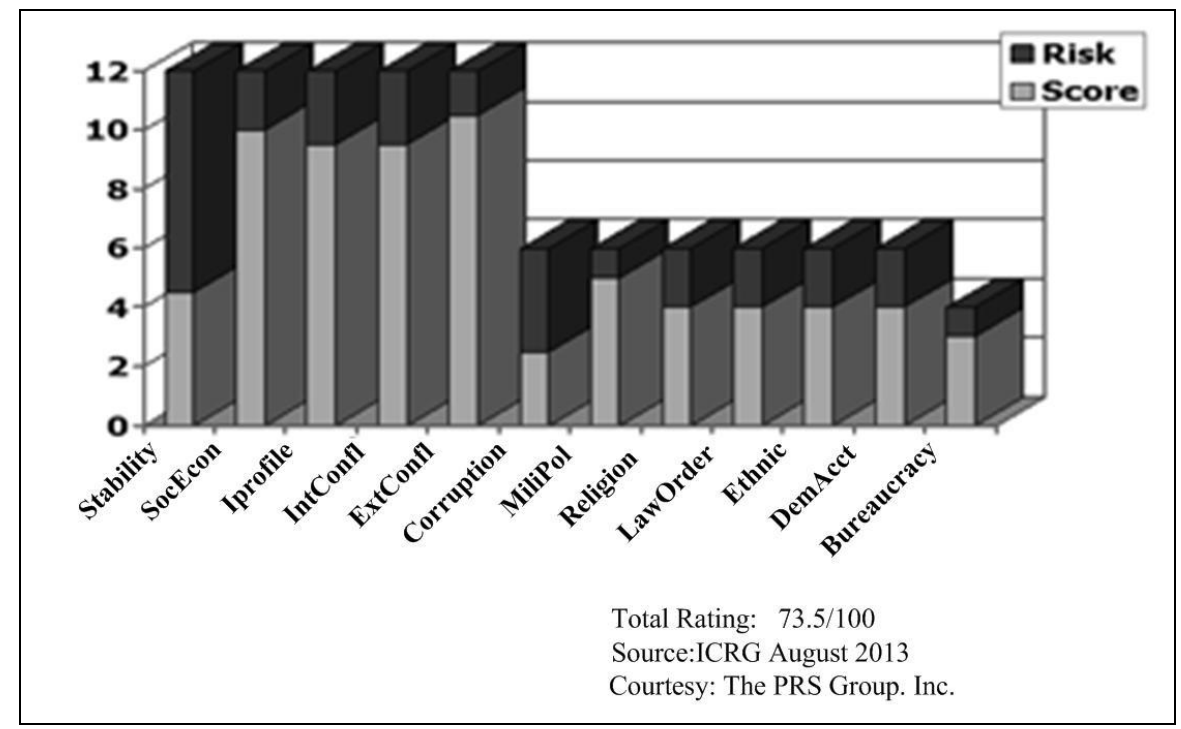

Figure 5. Malaysia ICRG assessment August 2013 ratings.

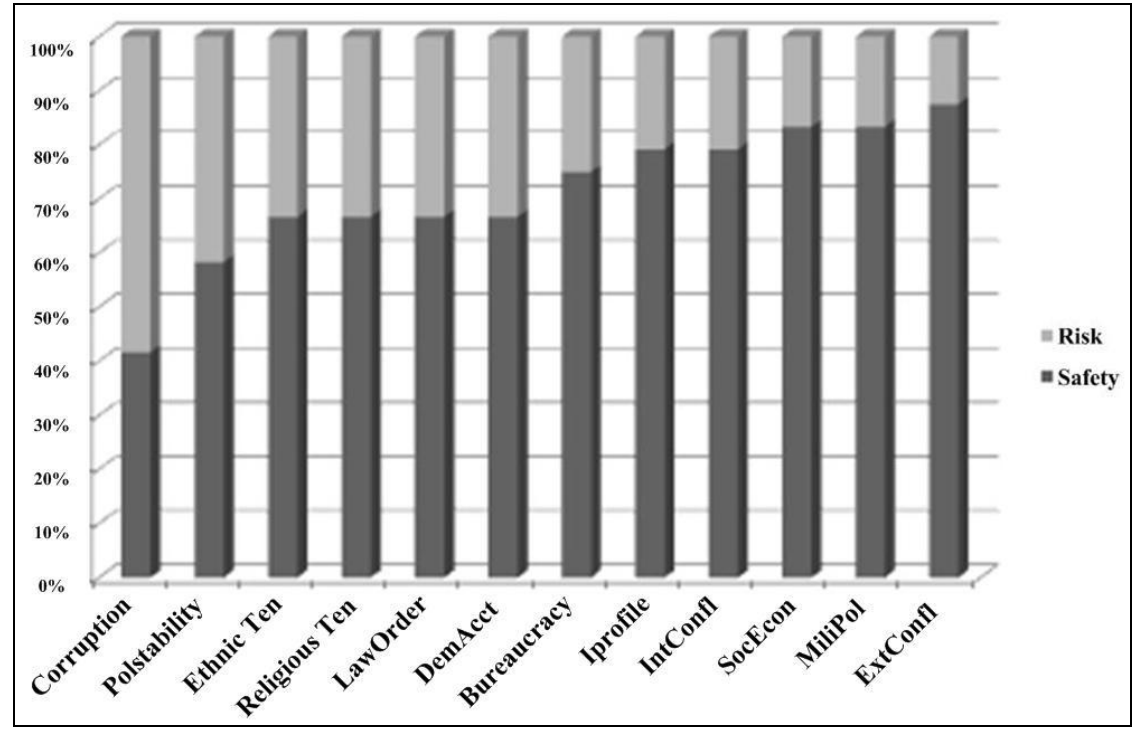

Figure 6. ICRG for Malaysia January 2014 standardized and ordered.

ICRG's five-year forecast (in Table 1 with a representative group of countries) is not as helpful to the investor as it should be. ICRG only provides "best case" and "worst case" estimates, giving some idea of where the country is likely to go but no indication of why. That is, it doesn't explain why the "Risk Stability" index (the difference between the worst case and the best case) is what it is. When scores for the specific variables are absent, the investor has no guide to where the sources of risk are and therefore have no guidance on what to do. Buy insurance? Get a private security company to guard the perimeter? Avoid the country altogether? The real 
additive of political risk analysis is to provide exactly this information. That is the forecast for the individual variables is what the investor is paying for. Here the investor is expected to provide the forecasting analysis and prescription itself.

Table 1

Malaysia Compared ICRG Five-year Forecast Comparisons 2014: Political Risk Rating Forecasts

\begin{tabular}{lllllllll}
\hline & & \multicolumn{3}{c}{ Current } & \multicolumn{3}{c}{ One-year forecast } & \multicolumn{3}{c}{ Five-year forecast } \\
\cline { 3 - 8 }$X$ & Country & Rating $01 / 14$ & Worst case & Best case & Risk stability & worst case & Best case & Risk stability \\
\hline 9 & Botswana & 72.5 & 69 & 76 & 7 & 67 & 79.5 & 12.5 \\
15 & Chile & 77.5 & 72.5 & 81.5 & 9 & 69.5 & 83.5 & 14 \\
16 & China & 59.5 & 54 & 65.5 & 11.5 & 50.5 & 69.5 & 19 \\
26 & Egypt & 48.5 & 46 & 55.5 & 9.5 & 46 & 63.5 & 17.5 \\
39 & Hong Kong & 75.5 & 72.5 & 80.5 & 8 & 72.5 & 83 & 10.5 \\
42 & Indonesia & 57.5 & 52 & 60.5 & 8.5 & 50.5 & 64 & 13.5 \\
53 & Malaysia & 73 & 67 & 75 & 8 & 63.5 & 79.5 & 16 \\
130 & Namibia & 75 & 69.5 & 78.5 & 9 & 66.5 & 79.5 & 13 \\
67 & Philippines & 61.5 & 58.5 & 65.5 & 7 & 55.5 & 70 & 14.5 \\
75 & Singapore & 83 & 78 & 88 & 10 & 74 & 91 & 17 \\
86 & Thailand & 55.5 & 48 & 60 & 12 & 48 & 69 & 21 \\
93 & United States & 79.5 & 77.5 & 85.5 & 8 & 77.5 & 88 & 10.5
\end{tabular}

The best that we can get from the ICRG data for the future is that a probability exists that says that Malaysia's total risk score will increase over five years. Splitting the risk stability score, then adding it to the worst-case scenario would give Malaysia a five-year rating of 71.5 as compared to its current rating of 73 .

The model from BERI (Business Environment Risk Intelligence) follows a similar pattern to that of ICRG (Hatipoglu, 2013). BERI has its origins in the 1970s with the early efforts of F. Ted Haner (Haner, \& Ewing, 1985). Its analysis of political risk (a PRI, Political Risk Index) includes ten variables, broken down into subcategories of Internal Causes (six), External Causes (two), and Symptoms (two) (Haner \& Ewing, 1985). The country analysts rate the country on a scale of zero (prohibitive problems) to seven (no problems) for Internal and External problems, with a bonus possibility for exceptionally good conditions (on top of a seven). They rate symptoms on the basis of zero to seven, with no bonus for these two variables. Thus, sevens for all ten variables would result in a 70, with potential bonuses accounting for another possible 30 . A score of seventy would thus be considered a good score, with higher scores resulting in very positive investment recommendations for the country, as a whole. The separate variable scores would still be needed in order to provide specific advice on insurance or alternatives.

The breakdown is as follows:

Six Internal Causes of Political Risk (each worth seven points with possibility of a bonus if the circumstance is exceptionally good): (1) Fractionalization of the political spectrum and the power of these factions; (2) Fractionalization by language, ethnic and/or religious groups and the power of these factions; (3) Restrictive (coercive) measures required to retain power; (4) Mentality, including xenophobia, nationalism, corruption, nepotism, willingness to compromise, etc.; (5) Social conditions, including population density and wealth distribution; and (6) Organization and strength of forces for a radical government.

Two External Causes of Political Risk (each worth seven points with possibility of a bonus if the circumstance is exceptionally good): Dependence on and/or importance to a major hostile power; and Negative 
influences of regional political forces.

Two Symptoms of Political Risk (each worth seven points but no bonus possibility): Societal conflict involving demonstration, strikes, and street violence; and Instability as perceived by non-constitutional changes, assassinations, and guerilla wars.

For the last assessment in 2013, BERI gave Malaysia an overall score of 50 for the present and broke the ratings down as shown in Figure 7. Here the ratings are standardized. For foreign investors to consider, the worst ratings for Malaysia are for Ethnic Fractionalization and Mentality, which prominently includes corruption. At the next level, Negative Regional Forces, Political Fractionalization, the Power of Radical Forces, and the Use of Restrictive Measures by the government are to be considered.

In Figure 8, the graph showing the five-year forecast projections indicate that Mentality (including corruption), Restrictive Measures by the government, and Ethnic Fractionalization head up the list of what needs attention by foreign investors.

After the variable names in Figure 9, a number appears if the BERI experts noted a change from the presence conditions. For six of the 10 variables there is a positive change of +1 . The other four variables stay the same for five years according to BERI's analysts. I'm something of a skeptic when everything improves over time. But this is what BERI's experts think.

There may be, however, a larger methodological problem with BERI. In their Political Risk Index Criteria Details for the third trimester of $2013,{ }^{11}$ for the 50 countries provided assessments, 11 have received bonus scores without first achieving an assessment of seven points for the variable. For example, Kazakhstan received five points out of seven for the variable Fractionalization of the Political Spectrum but it received three points as a bonus. Why is not clear. Overall, with 11 countries receiving bonuses without achieving a full score, $22 \%$ of the countries appear to have better scores than they would if BERI were following its own rules. But there are always variations like these. This is human intelligence, and it includes human variation.

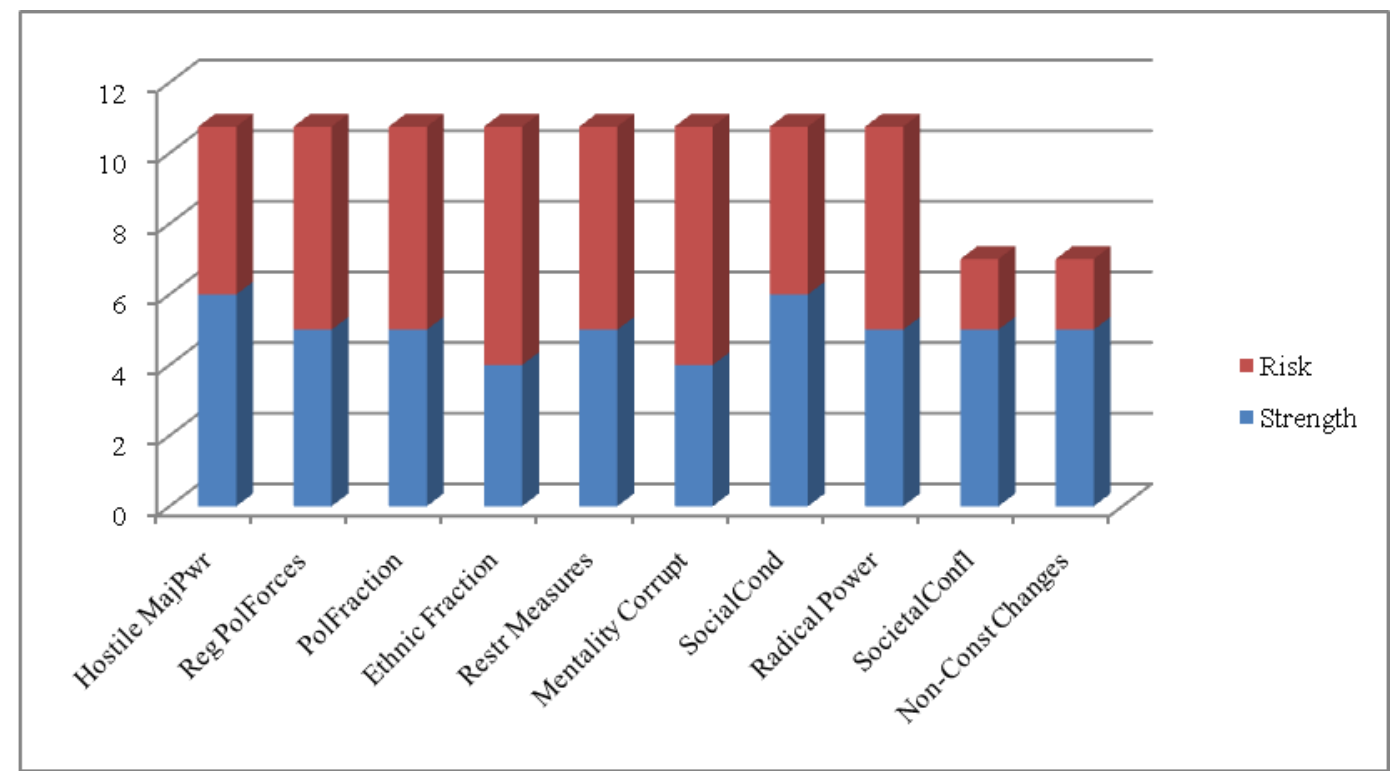

Figure 7. Malaysia BERI 2013-III present ratings.

\footnotetext{
${ }^{11}$ Business Risk Services 2013, III, p. 114.
} 


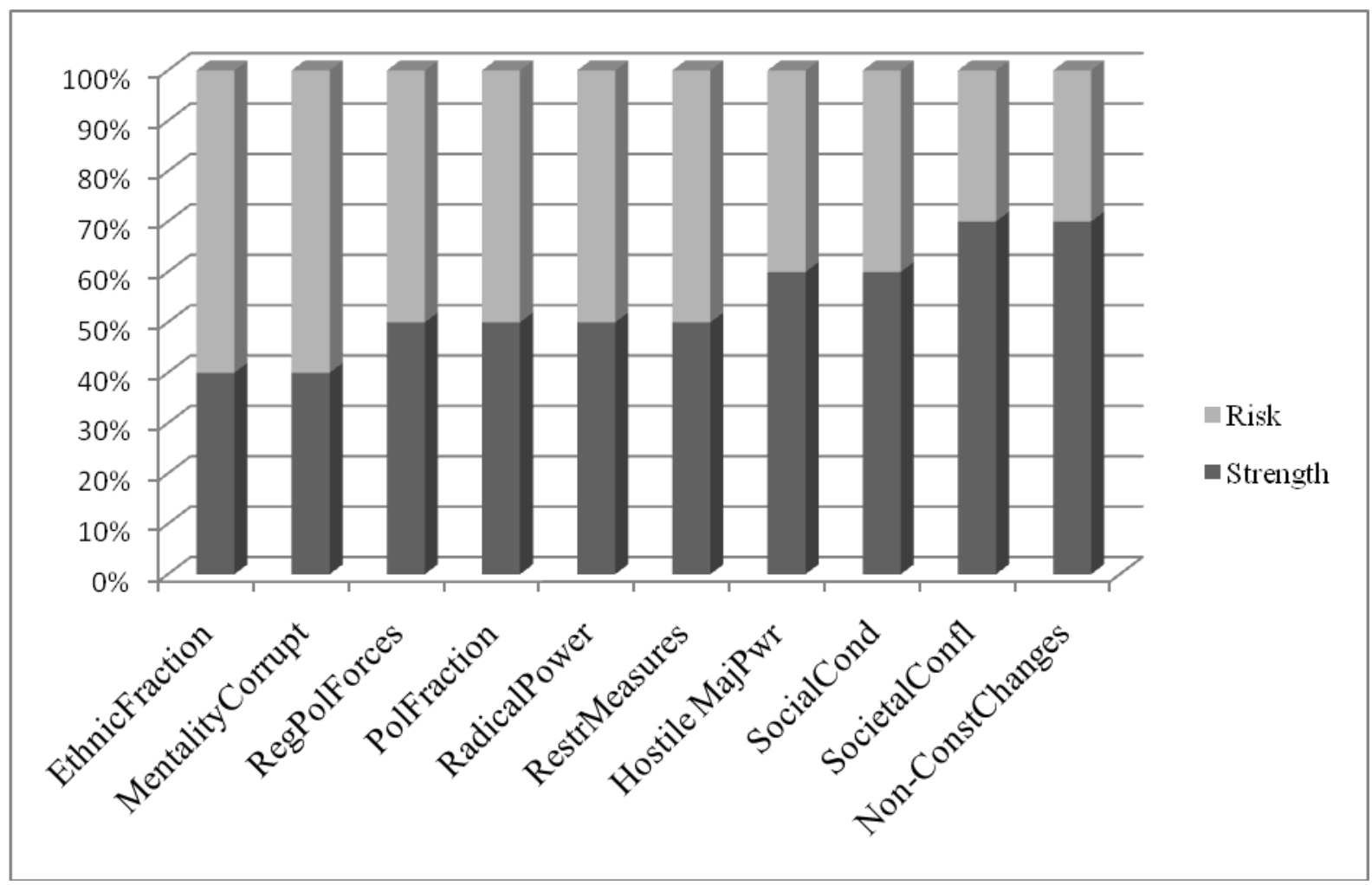

Figure 8. Malaysia BERI 2013-III present ratings standardized and ordered.

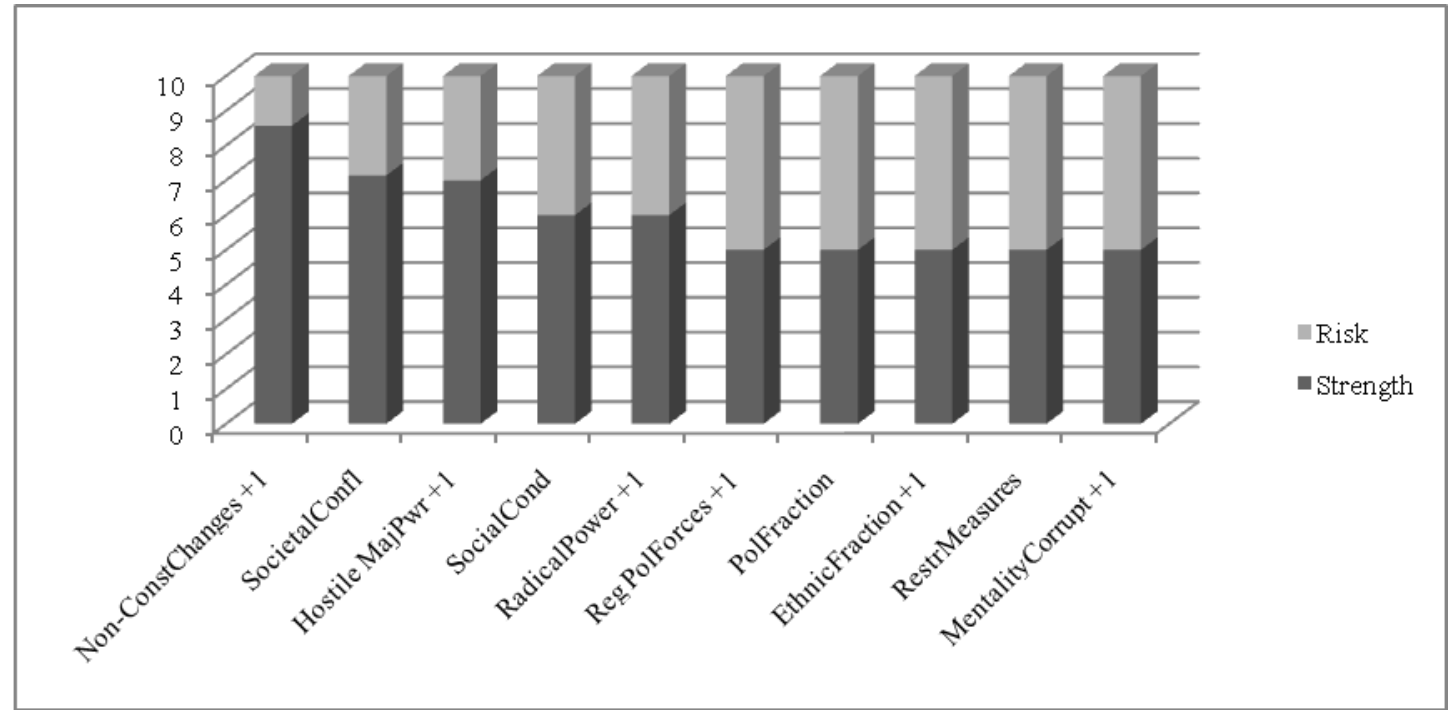

Figure 9. Malaysia BERI 2013-III five-year ratings (standardized).

\section{The Economist Political Risk Model as Organization}

In December of 1986 The Economist magazine provided a four page article entitled "Countries in Trouble: Who's on the Skids", in which the magazine's editors structured a country risk model and conducted an assessment for 50 countries. Among the 50 countries was the then "developing" economy of Malaysia. Despite Economist disclaimers, the model was constructed along the same lines as any country or political risk 
model in use in the commercial risk assessment sector at that time (very much along the lines of BERI and ICRG).

I need to answer up front the question of why I'm using this model rather than BERI or ICRG to provide an assessment of political risk in Malaysia. The Economist article was brought to my attention in 1987 while I was working, under the Fulbright Program, at INTAN, Malaysia's National Institute of Public Administration. A Malaysian economist (a Chinese Malaysian) dropped the article on my desk one day and asked me for my thoughts on it. He did so with a commentary, before I read it, that Malaysia's ratings were widely disputed by INTAN's analysts who had read it. Most of them were ethnic Malays.

I worked through their model and laid out a program to allow my Malaysian colleagues to work through it and see what they would have done differently, in the selection of variables, the weights they would have given them, and how they would have structured the assessment of political risk differently. Over the course of six workshops provided for Malaysian diplomats, Ministry of Defense officers, and police officers, I found that the main dispute they had was the inclusion of Islamic fundamentalism as one of the variables. About $90 \%$ of the other employees at INTAN were Malay Muslims, with a similar proportion in the participants in the workshops. Of course, they would want to eliminate this variable because it was a criticism of them.

They did. Part of the workshops was to restructure the model in a way that would still approach the question of political risk in the other countries that were being evaluated but include Malaysia. One of the approaches was to eliminate "Islamic Fundamentalism" and replace it with something like that for ICRG (Ethnic Tensions or Religious Tensions) or that of BERI (Fractionalization by language ethnic and/or religious groups in the power of these factions). And interestingly, when the participants used the Economist model, including the Islamic Fundamentalism variable, Malaysia did not fare any better than it had with Economist analysts. And in some cases it fared worse. When they modified it, the results were still the same. Malaysia fared poorly even then.

And as we will see below, the division on this variable remains the same. Among 35 interviewees in February 2014, 16 Malays in the group gave Islamic Fundamentalism a score of 1.5 out of four, above the level of one given in the original Economist assessment in 1986 (see Table 2 and Table 3). Non-Muslim Malaysians gave it a score of 2.5! Whether the Economist's model is an accurate one for forecasting political risk or not is one question, with the discovery of underlying stresses in Malaysia's society being another. The model turns out to be useful in the examination of the integral structure of Malaysia, or any country, whether its solution value is high or not.

The Economist's attribute model contains 16 Economic, Political, and Societal variables, the variables are weighted to reflect their relative theoretical importance, and the countries analyzed are rated on the basis of 100 total points and are ranked. The model was easy to understand, followed the basics of the scientific method, was widely read, and had great impact among its readership. This new and internally devised model, including political, social, and economic factors, provided a risk assessment and well stated method that had worldwide distribution, had global reactions, and raised some critical questions about both the nature of country risk and the nature of the world in which foreign investors operate. The editors of The Economist magazine developed the model and presented it in a four page article titled "Countries in Trouble: Who's on the Skids?" in $1986 .{ }^{12}$

12 “Countries in Trouble: Who's on the Skids?” The Economist, December 20, 1986, pp. 25-28. 
Table 2

Economist Model Outcomes

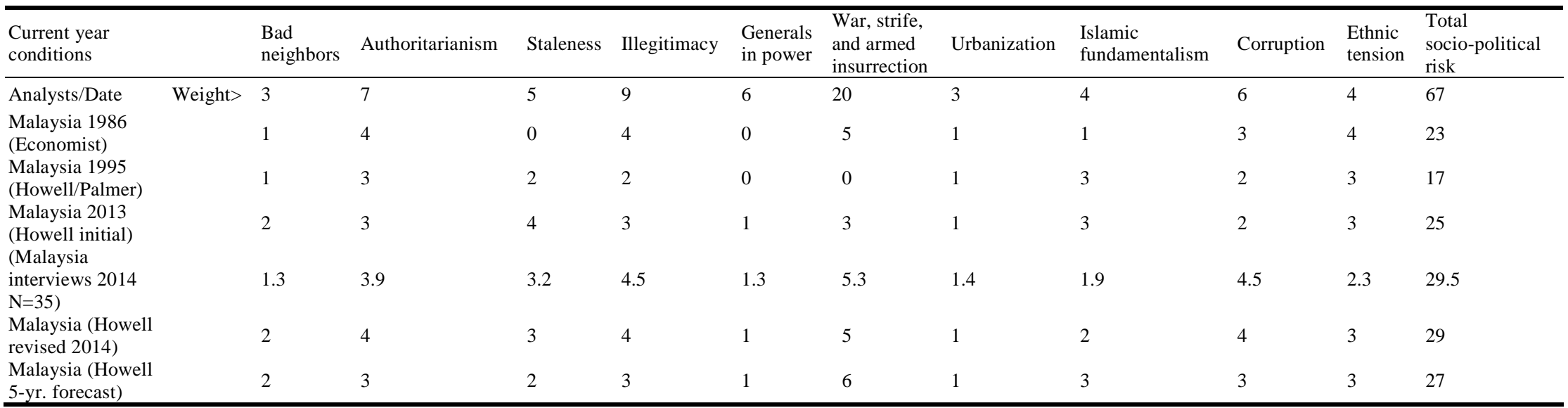

Table 3

Compared Economist Model Ratings All Subgroups

Economist Country Risk Model

Current year conditions

Bad neighbors Authoritarianism Staleness Illegitimacy $\begin{gathered}\text { Generals } \\ \text { in power }\end{gathered}$ War, strife,

AnalystiDate

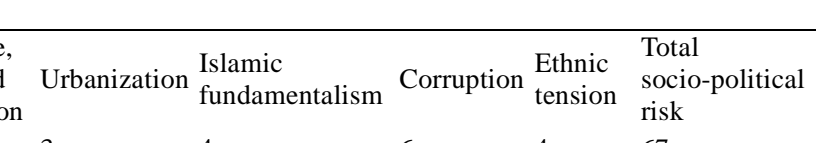

Malaysia 1986 (Economist)

Malaysia 1995 (Howell/Palmer)

Malaysia 2013 (Howell initial)

(Malaysia interviews 2014

$\mathrm{N}=35$ )

(Malaysians only $2014 \mathrm{~N}=27$ )

(Malays only $\mathrm{N}=16$ )

(Non-Malays $\mathrm{N}=11$ )

(Foreigners $\mathrm{N}=6$ )

(Females only $\mathrm{N}=18$ )

(Males only $\mathrm{N}=15$ )

\begin{tabular}{ll}
3 & 7 \\
1 & 4 \\
1 & 3 \\
2 & 3 \\
1.3 & 3.9 \\
1.3 & 4.1 \\
1.5 & 3.7 \\
1.0 & 4.6 \\
1.4 & 3.2 \\
1.4 & 3.6 \\
1.2 & 4.3 \\
2 & 4 \\
2 & 3 \\
\hline
\end{tabular}

$\begin{array}{lll}5 & 9 & 6 \\ 0 & 4 & 0 \\ 2 & 2 & 0 \\ 4 & 3 & 1 \\ 3.2 & 4.5 & 1.3 \\ 3.2 & 4.4 & 1.5 \\ 2.7 & 3.8 & 1.7 \\ 3.9 & 5.4 & 1.1 \\ 2.7 & 4.5 & 0.9 \\ 2.8 & 4.2 & 1.3 \\ 3.4 & 4.8 & 1.4 \\ 3 & 4 & 1 \\ 2 & 3 & 1\end{array}$

\begin{tabular}{lllllll} 
in power & insurrection & & fundamentalism & tension & risk \\
6 & 20 & 3 & 4 & 6 & 4 & 67 \\
0 & 5 & 1 & 1 & 3 & 4 & 23 \\
0 & 0 & 1 & 3 & 2 & 3 & 17 \\
1 & 3 & 1 & 3 & 2 & 3 & 25 \\
1.3 & 5.3 & 1.4 & 1.9 & 4.5 & 2.3 & 29.5 \\
1.5 & 5.3 & 1.4 & 1.9 & 4.4 & 2.3 & 29.7 \\
1.7 & 4.8 & 1.4 & 1.5 & 4.1 & 2.2 & 27.3 \\
1.1 & 6.2 & 1.4 & 2.5 & 4.7 & 2.5 & 33.3 \\
0.9 & 5.7 & 1.3 & 1.3 & 4.6 & 2.2 & 27.7 \\
1.3 & 5.0 & 1.4 & 1.6 & 4.3 & 2.3 & 27.8 \\
1.4 & 5.9 & 1.4 & 2.1 & 4.5 & 2.2 & 31.2 \\
1 & 5 & 1 & 2 & 4 & 3 & 29 \\
1 & 6 & 1 & 3 & 3 & 3 & 27 \\
\hline
\end{tabular}

Malaysia (Howell 5-yr.

forecast) 
The grounds for the dispute by Malays were three: first, the analysts there (mostly Malays) thought that the Malaysia score for Ethnic Tension or "Ethnic, Religious, and Racial Tension" (four negative points out of four possible) was excessive. Second, and particularly grating, was the fact that Singapore received a much better score than Malaysia did. Third, these Muslim Malays thought that "Islamic Fundamentalism" as a variable was prejudicial. At the time, well before the attacks of September 11,2001, others felt this way as well, thinking that a variable "Religious Fundamentalism" or even "Ethnic, Religious, Nationalist challenges" as it appears in BERI or "Religion in Politics" as it is in ICRG would be a better fit. Nevertheless, when the model was used in a research project with Malay Muslim civil servants, the Malays gave an even worse score to Malaysia than did the reporters from the Economist.

Nevertheless, grounds were laid for the application of the Economist model in Malaysia. It touched nerves in a way that drew attention and provoked thought about both how "foreigners" might look at Malaysia and how Malaysian decision makers might try to address the makeup of the investment environment.

Table 2 provides a summary of the weights for the 16 variables as they were initialized in the 1986 Economist article. $^{13}$ Their descriptions of the variables, the weighted values for each, and a brief rationale are provided from their original text below. Each variable was rated on a scale of zero to the weight assigned, with zero meaning no problem and the full weight meaning that the problem is as bad as it can get. This is in contrast to most rating methods (like BERI and ICRG) where more points are usually positive. In the Economist method, more points equal more risk or more trouble (hence, the term "Troublespots") in the title of the article. A country's government would want a low score in this measure. Few got them. This model looks specifically for trouble.

In this analysis, I will only be looking at the socio-political variables included in what is normally referred to as "political risk".

These concerns were kept in mind in both the 1995 assessment by Howell and Palmer and in the 2013 evaluation that I have made but the original variables and weights were kept in place as the conceptual structure.

The ratings companies do not publicize the number of country specialists they use for each country. Simply because of cost prohibitions, I suspect they often use only one, or even one for several countries. The human resource issues are important in the management of any business, including the political risk assessment business (Howell, 1986). Ordinarily, ratings are expected to be completed by more than one expert and then combined into the score that is used to compute an overall risk rating. BERI uses roughly 20 volunteer experts per country and then applies the Delphi technique to establish a single score that they publish. Some others do use as few as one expert. Either way, individual country experts are at the base of any country's rating. Is this then 'just a qualitative rating' that is in some way inferior to a "quantitative" rating? The answer is no (Howell, 2012). It is common medical practice to ask patients how they feel or if they have pain on a scale of 0 to 10 and use the answers to these questions to prescribe medications. They ask only one expert. Think about headaches. The Economist asked their experts about country headaches and then prescribed risk management. This is what I do in the section below, trying to provide a rationale that goes with the headache score.

Again, I'm only providing scores for the issues in the model that relate to political or social issues that result in some form of political risk insurance coverage or some other form of risk management on the part of foreign investors.

13 Table 3 breaks the group down into smaller components but this table should be used cautiously, since the subsamples are small. 


\section{Malaysia Viewed Through the Economist Lens}

I won't provide comments on every single cell in Table 2 or Table $3 .{ }^{14}$ I'll leave these for the reader draw on as appropriate to interest. And I will comment on some cells not shown. I broke the non-scientific sample of 35 Malaysian interviews down into their subsamples of Malaysians (vs. Non-Malaysians), Malays (vs. non-Malays vs. foreigners), and females vs. males. I'll selectively reference some of the subsample scores and differences but will refrain from displaying the details for confidentiality and sensitivity reasons. In any case, the 35 are all individually advisory to me as the country specialist. I still have to make the decisions about what I will provide as a score, just like every other specialist does with ICRG or BERI or PRS.

\section{Politics (50 points):}

The politics section of the model contained six variables. I'll provide the 1986 Economist definition for each, and then my score for 2014 based on the potential trouble that the model projected. With each variable I will provide my score, the score from the Malaysian interviewees, my revisions, and my projection for five years. I'll discuss the Societal variables in the same fashion.

(1) "Being near a superpower or troublespot" ("Bad Neighbors", 3 points). Ideology or no, great powers will be great powers. One of their central characteristics is to make sure their borders are secure. And they are likelier, on balance, to scrap with distasteful countries near their borders (Afghanistan, Nicaragua) than with more distant ones. It also does not help being near already disturbed places (like Iran, Iraq or South Africa)”.

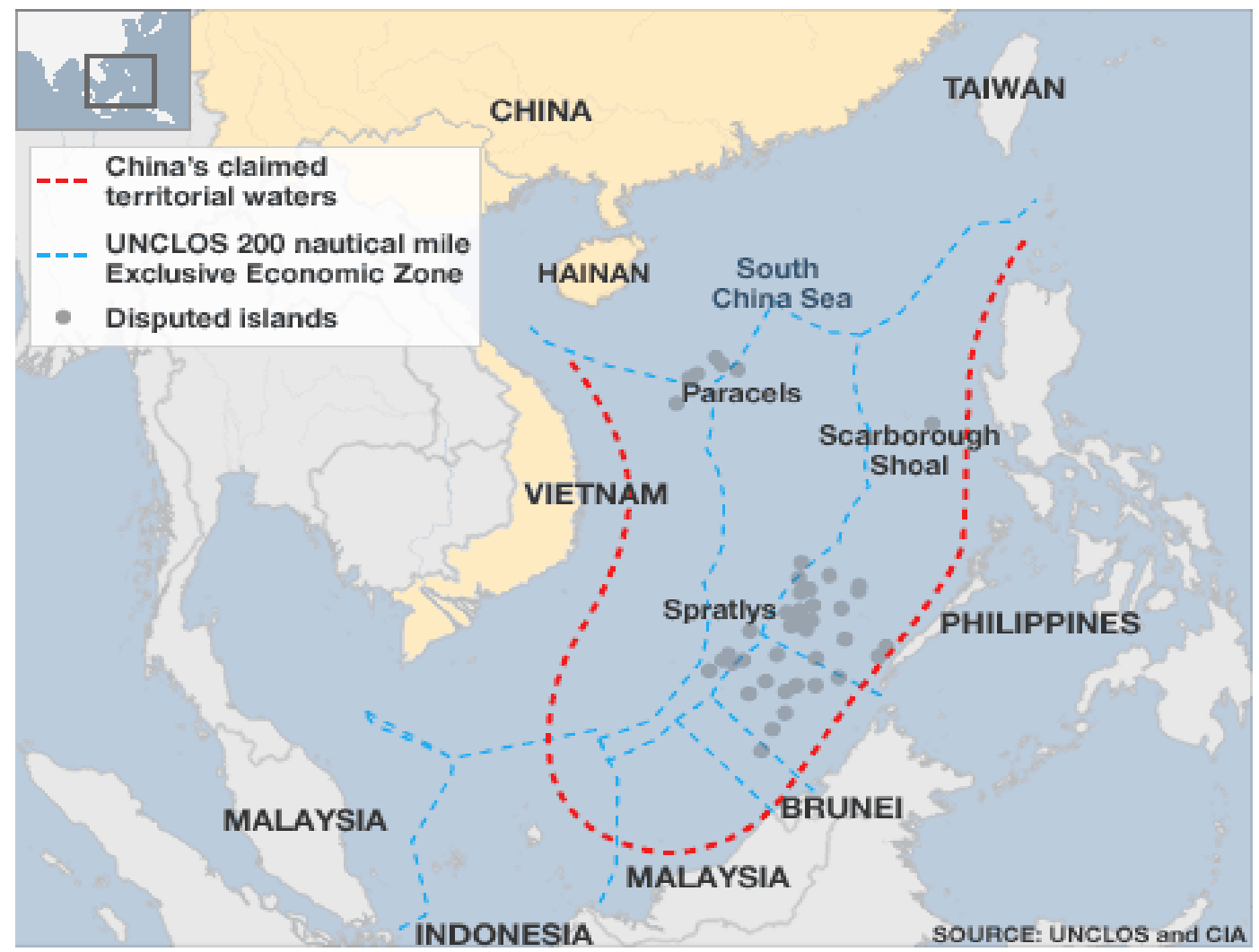

Figure 4. Economic Area Inside the Red Dotted Lines Claimed by China.

\footnotetext{
${ }^{14}$ Figures 9 and Table 3 provide the results from the survey, with the data broken down more finely but into groups that are too small to be statistically reliable. Nevertheless, the results in Table 3 are interesting and conform to what was learned in individual interviews for this study.
} 
Malaysia today has both more superpower problems and is in more of a trouble spot than it was in 1986 or 1995, when the score was one. Malaysia's ongoing dispute with China over the Spratly Islands ${ }^{15}$ has already laid the groundwork for a larger conflict. The handling of the disappearance of Malaysia Airlines flight and MH370 has resulted in Chinese naval forces in the form of search vessels to be present around Malaysia, through the Strait of Malacca, and into the Indian Ocean with surveillance and intelligence equipment. There were 157 Chinese aboard the flight, all of whom now are at the forefront of challenges regarding the confidence of the Malay led government. More challenges are to come. Just simple logic says that the score has to be higher (see Figure 4). I give it two out of three .

This variable introduces the international context to country and political risk analysis. Often, risk assessment focuses strongly or entirely on the conditions inside the country, especially when executives from the investing company are doing the risk assessment and spend their time with visits to the site or the countries major cities. But risk to businesses intending to invest in a particular country comes not only from conditions in the country but also conditions, actions, and intentions in the host country's neighbors, whether they are superpowers or not. Today's investors locating in Malaysia need to know about the extent of Islamic Fundamentalism in that country but also need to know about the Islamic insurrection in southern Thailand and the Islamic political groups operating in the area-Jemaah Islamiyah, the Abu Sayyaf Group, and the Moro Islamic Liberation Front (SAIS Conference Report, 2003). ${ }^{16}$

Malaysia has not been a particularly aggressive country in challenging its neighbors or reaching afar with a particularly aggressive foreign-policy. But there are several elements of Malaysia's situational context that generate challenges.

The first is Malaysia's claims in the South China Sea, most butting heads with the powerful Chinese Navy and claims by Beijing for the same islands and economic zones around them. Malaysia has been steadfast in these claims for the past thirty years or more. It doesn't have the armed forces to defend them and has to rely, therefore, on the international community, or, likely, the Americans who have the only force in the region that can send off the Chinese Navy. The Malaysian government is watching closely as the Chinese encroach (using this prejudicial word) on islands also claimed by Japan, South Korea, the Philippines, Brunei, Vietnam, and Indonesia. There is little that the Malaysians can do alone. With the United States being drawn in many directions at once, including Africa, the Middle East, and now Ukraine and Russia, there are no great expectations that Malaysia will be able to exert sovereignty. Fighting is unlikely. Malaysia would lose. China is expanding its military budget at rates of more than $10 \%$ per year. The prospect, therefore, is for major diplomatic disputes that manifest themselves in economic interchange, which themselves can turn out to be as costly as military conflicts.

The second is the turbulence in southern Thailand, where the population is predominantly Malay and Muslim, and where four provinces were once a part of British Malayan territory and sultanic rule. Rebels in Thailand, Malays opposing governance by Thai Buddhists and aligning themselves in some instances with terrorist groups from the region and beyond, fight along the border and sometimes slip into Malaysian territory. The similarity of ethnic groups on the two sides of the border provides a simmering basis for conflict between

\footnotetext{
15 Including China's recent efforts to build barriers and islands with structure, port facilities, and military emplacements on the reefs that constitute much of the Spratly Islands (NYT, April 10, 2015).

16 Also see the talk by Dr. Joseph Liow, "Extremism in Southeast Asia: The Challenge of ISIS/ISIL for Indonesia, Malaysia, and Singapore," at the ASEAN Studies Center, American University, April 24, 2015.
} 
Thailand and Malaysia. Economic border disputes between the two countries extend out into the waters on each side of the peninsula, occasionally developing disputes about fishing rights and other economic claims.

Third, Malaysia is a targeted destination for political and economic refugees from other countries in the region, especially those with Muslim populations. Indonesia, Bangladesh, and Afghanistan all contribute illegal immigrants who are attracted by both Malaysia's economic progress and its friendly Islamic environment.

Fourth, the Sulu Sultanate, that was situated around the Sulu Sea, has in recent times pressed against the Malaysian state of Sabah. In 2012, hundreds of warriors claiming to represent the Sultan "invaded" Sabah with the intent of claiming the land again as a part of the historic sultanate. The Malaysian military ultimately had to repel them, killing a reported 120. Although the Malaysian military and police ultimately controlled the situation and chased the claimants away, a claim on the land continues to exist not only among the Sulu Sultan's adherence but also with the Philippines government. The claim remains as an irritant, at least, in relations between the two countries. It is embedded in Malaysia's history stemming from the inclusion of Sabah in Malaysia when it was formed in 1963. Even with the death of the Sultan of Sulu in 2013, the Philippines' claim of sovereignty in Sabah remains outstanding, with petty disputes between the two countries over monetary exchange and transfer of luggage between the national airlines in their international airports.

Fifth, a historical rivalry with Singapore and the Singapore Chinese has left an apparently terminal distaste in the mouths of Malaysian and Singaporean officialdom. Centuries old in its origins, the mostly Malay Muslim population of Malaysia and the primarily Chinese population of Singapore bristle in a multitude of contacts. The competition between the two ethnic groups, each with a governmental base, shows up in such matters as fishing disputes (where do territorial waters begin and end?) and water supply (almost all of Singapore's water comes from reservoirs in Johore, the southernmost Malaysian state.

Sixth, Malaysia has chosen to participate in many UN peacekeeping missions, some of which involve active conflicts. This participation places their soldiers in harm's way and sometimes involves the apparent taking of sides.

When I initially approached MIDA, the Malaysian investment development Authority, when I was setting up interviews in 2014, their consular officers were reluctant to recognize that Malaysia was involved in so many international conflict issues. The evidence eventually persuaded them otherwise and some of MIDA's officers in Kuala Lumpur participated as interviewees for this study.

I gave this variable a score of two out of three, both before and after I conducted the interviews in Kuala Lumpur in 2014. The Malays in the study agreed, giving a score of 1.5 which would have been rounded up to 2.0 in the use of whole numbers. The non-Malays, however, mostly Chinese Malaysians, gave a score of only 1.0 (see Table 3). I'm more pessimistic than either group and stick with the score of two. For the future, I can't see any improvement on this score. Malaysia's handling of the search for MH370 didn't improve the situation and maybe made it worse. I'm hesitant about assigning a score of three out of three for the five-year forecast. Things could be worse, so I've assigned only a 2.0. New investors in Malaysia need to have some concern about what a conflict with China, especially, would do to the Malaysian economy. And its defense budget. And the nature of its alliances, both economic and military. Malaysia has long been a part of the nonaligned movement but it won't be able to stand alone against an aggressive China.

Malaysia also has to be concerned about its place in the Islamic world. It is a Sunni Islam government that is in power. The issue of Sunnis against Shia is not a big matter here (Gooch, 2011, March 24) but alliances with other Islamic states identify Malaysia as some kind of a partner in Islamic enterprises. When MH370 
disappeared, initial thoughts both inside the government and internationally were that the disappearance had something to do with Islamic terrorism. Even though this proved ultimately not to be the case (so far), the fact that the issue even arose has to do with the realities of Malaysian government linkages with some of these groups. The news media even raised the matter of the attacks of $9 / 11$ having to do with the planners being in Kuala Lumpur when they put together their strategy. The Malaysian government, in protecting their own investment environment, will need to incorporate these international sensitivities in determining their place in the global economy.

(2) Democratic, totalitarian, authoritarian (7 points). One reason why not all stable societies are good societies is that determined states dispose of forces powerful enough to keep whole populations quiet for a long time; this is, after all, the purpose of totalitarianism... Notwithstanding the powerful apparatus of modern communications, daily life for all but a tiny number of people is local life-what happens in their own town or village, or at the most in their own country, and in their own language.

Nothing more was said by the Economist in 1986, especially nothing about what democracy is and how to recognize it. In this sense, they succumbed to a common malady in the West of seeing democracy as a political normality. It's the same issue as being able to recognize others as having a culture but not being able to recognize or define one's own. Similarly, the Economist failed to distinguish between authoritarianism and totalitarianism. It was apparently all "nondemocratic" to them. In its "Democracy Index 2012" ${ }^{17}$ the Economist states that "There is no consensus on how to measure democracy, definitions of democracy are contested and there is an ongoing lively debate on the subject... there is no consensus within the US government on what constitutes a democracy" and "although the terms freedom and democracy are often used interchangeably, the two are not synonymous". And it goes on to suggest that "democracy can be seen as a set of practices and principles that institutionalize and thus ultimately protect freedom... the fundamental features of a democracy include government-based on majority rule and the consent of the governed, the existence of free and fair elections, the protection of minority rights and respect for basic human rights". ${ }^{18}$

Democracy, it can be said, is a cultural characteristic, not a political one. The notions of voter participation, especially, and a sense of civil order and civil law are specifically Western and Protestant and Calvinistic. It doesn't overlay any system of social justice and order that emanates from the family or tribe or ethnic group or race. In order for democracy to be appropriate, and to work, requires first that religion, as imposed from infancy, teach that order is derived from the role of individuals. Each individual.

It's a fallacy of those who create democracy indices for countries that one government superimposed on multiple cultures can have one sense of what democracy is. This is certainly a problem in talking about "Malaysia". For the major groups of Malay Muslims, Han Chinese, and Indians of multiple origins, each has its own sense of political organization. For each, some measure of what authoritarianism means would have to be established before it could be determined if there was "democracy" or not, and whether it was valued, or not. For Muslims, it may well be that authoritarianism is more consistent with religious beliefs than the vagaries of democracy. For the Han, Confucianism may be appropriately consistent with authoritarianism in an entirely different way than in an Islamic reference.

How do we handle this for multicultural society when foreigners and foreign investors are gauging the society in their terms, not in domestic terms? This is however, what the Economist was engaged in with its

17 The Economist Intelligence Unit, "Democracy index 2012: Democracy at a standstill”, 2013, p. 24.

18 Ibid, p. 25. 
minimalist definition. Out of seven negative points, in 1986 the Economist gave Malaysia four points. In 1995, we gave Malaysia a score of three points, one point better than the Economist had given, not so much because the Malaysian government had improved in permitting democracy but rather that the Economist had judged the government too harshly.

The Economist Intelligence Unit, in its recent "Democracy Index 2012" ranked Malaysia at 64 out of 167 countries. ${ }^{19}$ While not in good company (El Salvador, Peru, Hong Kong/China, Mongolia Serbia, and Moldova), Malaysia is in what is essentially a growing democracy category. Its overall score, out of 10, is 6.41 . On the sub-variable of "functioning of government," Malaysia does especially well with 7.86. It does poorly on "political participation" with the 5.56 and in civil liberties with 5.88 .

In 2014, I had initially left the score the same as it was in 1995. Based on the interviews, I raised the score to a four. The Malaysian interviewees were in agreement that the score should be higher. Based on their experience, the UMNO led government had ratcheted up its grip on the Malaysian electorate. Malays gave the government a score of 3.7 on "Authoritarianism" and non-Malays gave it a 4.6 (see Table 3). This is so even though the greatest symbol of authoritarianism in Malaysia, the Internal Security Act or ISA, has been abolished in the interim. The government has extensive police and security powers even without the ISA and periodically exercises them in news reporting and in control of public gatherings (Fuller, 2009, May 8). ${ }^{20}$ UMNO remains firmly in control of the National Front and the election process and thus in control of the country. ${ }^{21}$ However, UMNO's grip is fragile and thus marginal. The slow process of preparing the population for a different government than that of the Barisan Nasional has been a part of the increasingly narrow BN victories. Sooner or later others will gain access to governance. For the five-year forecast, I gave Malaysia a three again.

I should note here, that among the interviewees, especially among the Malaysians, there was some concern about what would happen in the course of a changeover from a government that had been in power for well more than half a century to one that was more sympathetic with the Chinese and Indian minorities. In the midst of the 1969 elections, when the opposition appeared to be leading and about to take control, rioting broke out on May 13, a date now synonymous with racial violence in the country. Several thousand lives were reportedly lost in the fighting. "May 13" is what worries people. Many Chinese still think that maybe they should just let it be, and enjoy their overwhelming control of economic life in Malaysia.

(3) Longevity of regime (five points). A ruler ought to last five years but no longer than eight or ten. It takes a few years to master an administration and public opinion; but anybody is stale or detached from reality after a decade at the top.

In 1986, the Economist ignored its own definition when it gave Malaysia is zero for staleness. Regimes are not about one person. Even in 1986 the medieval sense of a king being the absolute monarch and ruler of all he sees was long out of date. Political, economic, and social systems are far too complex for one person to even comprehend let alone manage. At most a single ruler symbolizes a regime. But a regime consists of at least a

\footnotetext{
19 The Economist Intelligence Unit, "Democracy index 2012: Democracy at a standstill”, 2013, p. 5.

${ }^{20}$ Reports in 2015 are of even greater tightening of government controls and the further imposition of Islamic law. "Malaysia: Sedition Law to Be Reinforced", New York Times, Nov. 28, 2014, p. A10; Thomas Fuller, Malaysia Resurrects Detention Without Trial, Alarming Government Critics", New York Times, April 7, 2015, online; Austin Ramzy, "Editors and Executives of News Website Malaysian Insider Are Arrested", New York Times, March 31, 2015, online.

${ }^{21}$ Reported on by Joe Cochrane, "Malaysia's governing coalition keeps hold on power", The New York Times, May 6, 2013, p. A7 and The Financial Times, "A pyrrhic victory in Malaysia", The Financial Times, May 6, 2013, online, with the subheadline "The country's prime minister must ditch race-based politics".
} 
clique, if not an elite group that manages a society or country. UMNO has ruled Malaysia since its inception as Malaya in 1957. We recognized this in our 1995 study and gave Malaysia a score of two.

Now, 19 years later, UMNO still runs the country with a tight grip. Its failure has been to not accommodate education levels, desire for popular participation, information available in the news and on the Internet, the growth of population, the ability of other nations to view political processes inside the country, and the simple desire for freedom as experienced by its own citizens when they are in the West. Malaysia, and UMNO, earned, in my view, a solid 4 out of 5 on this count. Malay interviewees disagreed strongly, as one might expect. They gave Malaysia a 2.7, greater than our two in 1995 but still less by far than the four that I had initially assigned. Foreigners in my sample agreed, also at 2.7. Even though the non-Malays in the sample scored the country's government much higher at 3.9, all were short of my score. I took this as advice and gave Malaysia a score of 3 for 2014.

My discussions with the Malaysians led me to believe that the BN government was learning, and recognizing the nature of the challenge from the opposition parties. While the government has no intention to cede power, it is making some attempt to overcome the complacency that comes with staleness. This is difficult with an embedded Malay royalty and aristocracy that cannot be displaced no matter who is in power. One way or another, either with an opposition victory in the next national election no later than 2018 or by some transformative changes in the ruling coalition, I expect longevity of the regime to be less of a problem for foreign investors in five years than it has been in the past. I rate Malaysia as a two for the five-year forecast. There is little worry here.

(4) Legitimacy of regime (9 points). This is one of the weightiest but least calculable measures of a country's health. A government of any kind (short of Kampuchea's mad Khmer Rouge "administration" in the 1970's) depends somehow on the consent of the people it is ruling. It can err a good deal while still seeming legitimate: but once a country's people have stopped "believing" in it the government is finished—and so, until it goes, is the country's stability.

"Legitimacy" is very difficult to gauge when one uses the rather archaic concept and phraseology of "consent of the people". Who are "the people?" In Malaysia's case the people are very diverse and clearly divided population. Just as in the United States, the division between Republicans and Democrats has become increasingly a division between Whites and non-Whites, in Malaysia you always know that Chinese and Indians are not members of UMNO. Whether the government is legitimate depends on who is judging it. Malays and Muslims judge it differently than Chinese and others. UMNO protects the rights of Malay Muslims. They see this protection as part of their heritage, their right to the land, and their right to political power. In the eyes of most Malays, the government is legitimate, whether it is democratic or not. In its 1986 study, the Economist gave Malaysia a score of four. It was our impression in 1995 that this score reflected the view of the Economist's reporters and Western standards, not the view of Malaysians, let alone UMNO partisans. We gave the country a score of two.

In 2014, there has been some change. Among the ruling Malay Muslims, there is now a three way division. UMNO supporters see the current constitution and the process of governance as still being appropriate. Conservative Malays on the right dismiss the government as being reflective of original British intentions to leave the old Malay monarchy in place for the indefinite future. They want revisions in government that would reflect the interests of Islam, especially with the imposition of Sharia law. On the left, however, there is a growing cadre of Western-educated and oriented Malays, led by former Deputy Prime Minister Anwar 
Ibrahim. $^{22}$

I have more confidence that there is a grudging acceptance among the UMNO leadership that they need to lead change in the country. Ironically, the national and international response to the government's handling of the MH 370 disappearance will, I think, be a part of putting the BN government on the world stage and press its transformation, assuming that it remains in power. Even though both Malays and non-Malays scored the country higher on this variable ( 3.8 and 5.4 respectively), my view is that the compact that was made in the 1950s to set Malaya's independence is more broadly understood by the broader population of Malaysia then it is accepted by the elites that composed my study. For them the arrangement still works. I give Malaysia a three in my five-year forecast and suggest that foreign investors have greater concerns elsewhere.

(5) Generals in power (6 points). The men in uniform sometimes have to take over. Once there, however, they usually become destabilizing. Most of them know neither how to govern nor how to step aside gracefully.

The most important thing to know about the Malaysian military is that it is about $90 \%$ Malay and Muslim. In the event that it would be used domestically, as during the 1969 riots, it would most likely be used to control the country's minorities; that is, the Chinese. This intimidating fact plays a critical role in the relationship between the military and governance by UMNO and the Malay elite.

As it is, the Army has no real experience at domestic management, that is, in dealing with Malays and Chinese. It has, though, considerable experience through UN peacekeeping assignments around the world.

However, Malaysia is facing an increasing number of external threats that have given responsibility to its generals and admirals in maintaining the integrity of the state. As their responsibilities have grown with respect to, especially, Chinese incursions and claims on Malaysian territory. There is some element, through responsibility, of military power in the modern Malaysian state. It may grow but for the moment it merits at least a score of one out of the six potential negative points that could be assigned, certainly something more than the zero points assigned in 1986 and 1995.

The MH370 incident exposed Malaysia's military more than any previous action. Many of the delays in providing information were the result of trying to keep concealed Malaysia's military and technological capabilities. In some cases, their actions were profound failures such as in the initial inability to note the aircraft when it was passing over the country on its way to its eventual fate somewhere in the Indian Ocean. In others, however, both their technological capabilities and their abilities to interact with international military and intelligence organizations proved effective and positive. There will obviously be reassessments of the military's capabilities and its role in Malaysia. In the meantime, the military remains a professional partner in Malaysia's governance, subjected to civilian control and not a threat to democratic processes.

(6) Armed insurrection or war (20 points). Real war — civil or (even bigger) international—overwhelms everything else in public life. Today's biggest and most destabilizing is the six-year-old war between Iraq and Iran.

The most immediate need with this war variable is to distinguish between civil and international war. A civil war will have immediate effects for businesses in terms of potential damage to facilities, disruption of transportation and supplies, and the labor market. An international war might be exacting a great toll on the country but may be fought entirely in another country, such as, for the US, with the American invasion and war in Iraq. The weighting of this variable is supportable but analysts have difficulty in placing countries on the

\footnotetext{
${ }^{22}$ As of this writing, Mr. Anwar has been convicted of a charge of sodomy and has been sentenced to five years in prison. His petition for a Royal pardon has been rejected as of March 31, 2015
} 


\section{0-20 continuum.}

ICRG has divided a similar war variable into two, civil and international, weighted equally at 12 points each out of 100. Without having some theoretical explanation of how the two types of war are combined, many of the Economist's scores seem without foundation and, because of the heavy weight given to war, call into question the distribution of total scores in their index.

In 1986 the Economist assigned five points out of the total 20 that were possible for this variable. No explanation was provided in the survey of events and circumstances in Malaysia's environment in 1986 and it shows neither cross-border conflict nor any indication of armed insurrection. The communist party armed insurgency had nearly completely ebbed in 1986. Its leader, Chin Peng, had retreated into Thailand and his challenge to the country was token. He finally ended the rebellion in 1989 and sought reconciliation with the Malaysian government. It was denied and Chin Peng retreated to Bangkok where he remained until his death in 2013. Palmer and I assigned a score of zero in 1995. In 2014, however, frequent naval challenges from the Chinese, and Malaysian peacekeeping missions that put troops in danger merit some score. I initially assigned a score of three, all on the international side if we were dividing the 20 points as ICRG does. This would be 3 out of 10 on the international side and zero on the domestic side.

I had to reassess this conclusion after talking with the interviewees, and after events in early 2014. All of the interviewees were of the view that both internal strife and external conflict, with China, were more likely than I had thought. Malays were concerned about China, while the non-Malays were concerned about internal strife and even insurrection. The May 13 syndrome. The feelings were strong enough, on both counts, that I raised my own score to agree with theirs, a five out of 20. And for five years I even added a point that made the score a six. My concern is China, on two counts. The first is the expansion of China's military and its encroachment on other islands (than the Spratlys) in the South China Sea ${ }^{23}$ and north into Island areas between Japan, South Korea, Taiwan, and China. The second is that as China expands its sphere of influence there will be an effect on Chinese populations in Southeast Asia, especially on that of Malaysia. The effect will be to embolden Chinese activists who are pushing for a greater role in Malaysian politics and overturning of the compact that was a part of Malaysia's creation.

\section{Society (17 points):}

(7) Urbanization (three points). The movement of people off the land and into cities is an inevitable consequence of economic development. But if it happens too fast, and if the movement is too concentrated on a single city, it creates difficulties of its own (idleness and crime) and is a sign of other things going wrong (such as pricing policies on food).

This variable is not just about how urbanized the country is. It is clearly about the pace of urbanization and the ability of the government to manage it. In 2013, Malaysia is clearly a rapidly urbanizing and developing country. Its main cities, especially Kuala Lumpur and Penang are modern, clean, attractive, and, for the most part, well-managed. Other urban centers like Malacca, Johore Baru, Ipoh, and Kota Kinabalu are faring well. Malaysia does have an immigration problem with migrants constantly pressing at the West Coast of Malaysia. Most of these are illegal immigrants. But Malaysian authorities are dealing with them relatively well. Well enough that unemployment and crime are not out of hand and prices remain within the reach of the country's

\footnotetext{
${ }^{23}$ See "Chinese Mischief at Mischief Reef", New York Times editorial, April 11, 2015; Reuters, "Images Show Rapic Chinese Progress on New China Sea Airstrip", New York Times, April 17, 2015, online.
} 
growing population. There is something here that needs to be recognized and so, as in 1986 and 1995, a score of one out of three has been assigned.

The interviewees essentially agreed. And there was no disagreement among them with scores of 1.3 or 1.4 across all of the subgroups. Urbanization has not been enveloping problem in Malaysia. Although Kuala Lumpur has grown dramatically over the last several decades, still remains a comfortable city with contemporary suburbs and good accommodations. Government planners have done well to keep city resources, power, water, and sewage treatment, within their control. Malaysia rates a one out of three for the five-year forecast. Kuala Lumpur and the country are welcoming to foreign guests and it is a comfortable environment for them.

(8) Islamic fundamentalism (four points). There was never much political fervor in Hinduism or Buddhism: Christianity is a spent force in Europe and, while it has social strength in the United States, Latin America and Africa, it is not (despite liberation theologians) going to raise big political storms in those places. But Islam today has the force and the political implications that Christianity had in Europe centuries ago. The Muslim radicals could still change the world - and where they are strong, stability is not.

Well before even the first attack on the World Trade Center by Muslim radicals (1993), the Economist model gave emphasis to radical Islam in establishing risk. Where BERI, ICRG, and others included a more generalized religion variable in assessing risk, the Economist went directly to a point made frequently away from formats subject to political correctness. While there was backlash from the Muslim world to this inclusion, in retrospect it seems that the Economist came closer to a realization of the impact of politicized religion than the other models. Islam has "social strength", other religions do not. And the variable phrased as Islamic Fundamentalism also gained support from Samuel Huntington's 1996 thesis in The Clash of Civilizations and the Remaking of World Order and then in other texts written after September 11, 2001 (Huntington, 1996; Armstrong, 2000; Manji, 2003; Stern, 2004). With this brief but provocative article, the Economist opened a discussion that has yet to be fully explored. They included the Islamic fundamentalism variable and gave it a score of one out of four.

In addition to the Malaysian diplomats who objected to the inclusion of this particular variable in any risk analysis, many academicians, writers, and social commentators criticized the Economist method for focusing on Islam rather than on religious influences in general. The critics saw the methodology as being particularly Western in its viewpoint and thus prejudicial in its analysis. Nevertheless, when Malaysian (almost all Malay Muslims) diplomats had an opportunity to score their own country on this variable, they gave it a three out of four. Palmer and I gave that same score in 1995.

Initially, I gave it a three in my 2014 assessment. It is not just the impact of PAS within Malaysia that is important to consider here but also the impact of Islam globally. Before September 11, 2001, we thought of and Islamic presence in one way today we think of it in another. Islamic groups do not work in isolation and the networks that run from the southern Philippines to Mumbai to Pakistan and to Saudi Arabia and Yemen are clearly important. But the Malaysian interviewees, both in combination and separately, gave a lower score. Non-Malays were the most concerned, scoring Islamic fundamentalism at 2.5, while Malays gave it only a 1.5. All, however, were at a lower score than I was. Even the small group of foreigners among the interviewees gave it a lower score at 1.3. So I have conceded a point here and in my revised scores have given Islamic fundamentalism only a two. But there has been a growing intrusion of Islam in the country as indicated by the increased wearing of Islamic head covers and a recent decision by the Supreme Court supporting the 
prohibition of the use of the name Allah by anyone other than Muslims. The government seems to be backing into the security of Islam facing growing influences of secularism, of the West, and of China. ${ }^{24}$ For the five-year forecast, I put Islamic fundamentalism back at a score of three out of four. It's a growing threat.

(9) Corruption (six points). Dogmatism about corruption is misplaced. Developing countries need mechanisms to move them from the political and family relations on which primitive societies base their economic transactions to the marketplaces on which advanced societies base theirs. Lacking other mechanisms they often need black markets and the like. This is why the "corruption" Chinese communist rulers were shocked by once they started opening their country's economy was in fact an encouraging sign.

Although their definition implies that corruption might be a good or useful thing, the scores from the analysts said otherwise. In 1986, the Economist gave Malaysia a score of three for corruption. In the years that have followed, development and growth within the country have offered greatly opportunities for bribery and corrupt practices. However, Palmer and I looked at the situation in 1995 relative to those in other countries where development was increasing at a similar or even greater rate. As political scandals in China and building collapses in Bangladesh attest, the problem is a global one. In that context, we felt that Malaysia was in a similar situation to those of other developing and developed countries in its category and that the score of two was more appropriate.

It was on this variable that I had to make the most adjustment, given the positions of the interviewees. As a group their score was 2.5 points higher than my own. Malays gave the variable a score of 4.1 and non-Malays of 4.7 (see Table 2). This difference was accounted for by suggestions from the Chinese side that the Malay royalty was at the core of their corrupt system, where Chinese businesses and foreigners paid into personal coffers to support the multitude of royal palaces (nine of the 11 peninsular states of Malaysia have sultans and the titular head of state is one of those nine sultans, the Agong). While it is not only disrespectful but illegal to criticize the sultans, it is still done in ordinary conversation outside of interview circumstances and away from the ears of Malays. I changed my score from a 2 to a $4 .^{25}$

Other sources confirm that my initial score of two was too low. Transparency International, an NGO that follows issues of corruption closely and rates countries based on the perceptions of business people who work in them, rated Malaysia for 2013 just at the margin of what they would otherwise call "a serious corruption problem" (Transparency International, 2013). Malaysia's score is 50 out of 100 and it is ranked 53rd out of 175 countries. Political \& Economic Risk Consultancy Ltd. (PERC), a company that advises investors in Asia, does an annual review of corruption in the region. In its 2013 assessment, it rates Malaysia in the middle with a score of 5.38 out of ten, with 10 being the worst score. ${ }^{26}$ Singapore is at the top with a score of 0.74 .

It's the communications technology age and even the Malaysian semi-controlled media are reporting on the costs of corruption to the country's economy and its image. It's a difficult problem for an embedded elite to get a grip on but Malaysia's chief rival, Singapore, has done it and rubbing it in by the national and

\footnotetext{
${ }^{24}$ In "Islam on the Fringes," USA Today Magazine, May 2014, p. 53, I argue that "Islam may be pushing its growing population out, but other civilizations clearly are pushing back...."

${ }^{25}$ In a lengthy analysis of the relationship between business elites, on the one hand, and the Malay royal and political elite families on the other, Louise Story and Stephanie Saul report in the New York Times on the details of a relationship between businessman Jho Low and Mr. Riza Aziz, step-son of Prime Minister Najib Razak that involved billions of dollars of exchanges. See Louise Story and Stephanie Saul, "Well Connected at Home, Malaysian Invests in US," The New York Times, February 9 , 2015, pp. A1, A10-A11. The story illustrates well how Malaysian corruption works and to what extent it prevails.

26 Asian intelligence: corruption's impact on the business environment. Political \& Economic Risk Consultancy Ltd., March 20, 2013, p. 1.
} 
international media will help. I expect improvements over the next five years. In the meantime, foreign investors need to tread carefully if they want to invest in this country successfully.

(10) Ethnic, religious and racial tension (four points). Northern Ireland, Sri Lanka and Malaysia have shown how much damage can be done to a country when the people are pompous enough to believe that skin color, religious belief or parentage are anything other than a source of happy variety.

Some of what is being measured by the ethnic, religious, and racial tensions variables is intertwined with other variables in the Economist model. This is especially so with Islamic fundamentalism. Malays are by constitutional definition also Muslims in Malaysia. As Malay-Muslims they have rights and privileges that the others do not have. That is, the other half of the population. A natural outcome of this provision is tension between the hard-working Chinese and the Malays who run the government or farm in the fields.

This paper presented a short treatise on race in Malaysia for good reason. This is the key variable and guide to all of Malaysian politics, and it has been for the last century (Howell, 2015). A major part of the reason that the British and Malay establishment could defeat the rebellion pursued by the Communist Party of Malaya is that virtually no Malays participated on the communist side, and few Indians. The rebels were all Chinese. They could be and were separated out from the Malay and Indian populations by placing Chinese villagers in surrounded compounds. Various other strategies eliminate it $60 \%$ of the population of the country by simply focusing on recognizable Chinese.

Recognizing the other races by their appearance has always been the key to Malayan and Malaysian society. Malaysians are extremely color conscious, even within one's own race. For hundreds of years, and before the British came, skin color was an indicator of value and place in society. Malay royalty would import wives from Thailand or elsewhere in order to get a lighter skinned wife and thus lighter skinned and more valued children (Howell, 2012).

Among Chinese and Indians this value was the same. Males in each racial group sought out lighter skinned females for marriage and reproduction. First color, then culture (including religion), then social status, then global region of origin (for example, Tamils from southern India with their very dark skin versus Caucasian Indians from the north), and other factors like wealth or occupation were the criteria for hierarchy. As it was so 100 years ago, it is still this way today in Malaysia.

Human beings of every variety use some criteria to establish inner circles and outer societal perimeters. It's a fact of life rather than a reflection of pomposity. Nevertheless, tensions from these sources affect hiring and management practices, have to be considered in sales and marketing, introduce rigidity to government, and turn into violence. This variable should be included in any political risk model. Among the problems to be recognized with operationalization, though, are overlapped with the Islamic Fundamentalism variable and the confusion that exists with the terms. Ethnicity, for example, includes race and religion, along with language and culture and some clarity about the terms is needed to help the expert judges sort out the range that can exist along this spectrum.

In 1986, the Economist rated Ethnic Tension at a four, out of four. This was clearly too much. While Malaysian society is divided into ethnic groups that are distinctly different in skin color, physical appearance, and dress, they are not constantly at odds nor in open conflict. The score has to be something less than full. Palmer and I rated Malaysia at a three on Ethnic Tension in 1995. Initially I had assigned the same score given my observations from the outside. My discussions with the interviewees and their own ratings gave strong 
evidence to a lower score than a three out of four. All of the subgroup scores were between 2.2 and 2.5. I lowered my rating to a two for present circumstances. The fact that the society had held together so well over the fractious year of 2013 is convincing in this regard. The question now becomes "how will the electorate, on both sides Malay and non-Malay, deal with an impending government that is outside the 1957 compact". It will be a touchy transition. I still think that a rating of three is appropriate for the five-year forecast. For the foreseeable future, foreign investors will need to step carefully around ethnic issues in Malaysia, as Malaysians themselves do.

\section{Conclusions}

The questionnaire answers and the discussions with the Malaysians changed my mind, a little bit, on a couple of variables. First of all, it was clear that they thought that the level of corruption was much higher than I did. I changed my assessment from two to four. They also made a convincing argument that the level of War and Strife, and Armed Insurrection was higher than I estimated and changed my score from three to five. At the time of these interviews there were a considerable number of news reports on mainland Chinese challenges to ownership of various islands in the South and East China Seas, where Malaysia also has claims. The conflict that has arisen between Malaysia Airlines and China, as represented in the Chinese families and their lawyers following the loss of MH 370, adds to a growing concern about China, an increasingly Bad Neighbor.

Still, the two variables that generate the most concern for foreign investors are ethnic tension and Islamic fundamentalism (see Table 4). Both, or either, could present a dramatic disturbance in the society and in its economy. Bad neighbors follow closely behind, and then the Malaysians' own primary concern of corruption. I have to recognize that the score the Malaysian interviewees gave to corruption indicated that it was their greatest concern, rather than ethnic or Islamic issues which took second place. Other matters, like the extent of Western democracy or the staleness of the government were left to be dealt with later. Otherwise we agreed on most counts (see Figure 11).

Table 4

Compared Investor Risk in Malaysia 2019 (Top Ranks by Risk Negatives).

\begin{tabular}{lll}
\hline ICRG (Based on Present) December 2013 & BERI (5-year forecast) Issue 2014-I & $\begin{array}{l}\text { Economist method (5-year forecast) } \\
\text { February 2014 }\end{array}$ \\
\hline Corruption 3.5/6 & Mentality/Corruption 6/11 & Ethnic Tension 3/4 \\
Government Stability 4.5/12 & Restrictive Measures 6/11 & Islamic Fundamentalism 3/4 \\
Ethnic Tension 2/6 & Ethnic Fractionalization 6/11 & Bad Neighbors 2/3 \\
Religious Tension 2/6 & Political Fractionalization 6/11 & Corruption 3/6 \\
Law and Order 2/6 & Regional Political Forces 6/11 & \\
Democratic Accountability 2/6 & & \\
\hline
\end{tabular}

Note. ICRG and BERI ratios have been inverted to match the Economist rating, where high numbers indicate a worse rating.

The variables with high risk scores from the three different methodologies ${ }^{27}$ are listed in Table 4. Corruption appears in all three "top four" (or ties). Here the investor needs to be cognizant of the legal ramifications not only in the host country but in the country of the investor's origin (hence the concern about

\footnotetext{
27 The Economist method provides its forecasts in the negative; that is, a zero means no problems and a number is an indication of how much of a problem. This is the risk. Those scores have been provided in Figure 5 as assessed. The ICRG and BERI scores have been inverted to match those of the Economist method, so they also indicate risk and the ratings can be compared across the table.
} 
the Foreign Corrupt Practices Act and a variety of OECD regulations). The management alternative that has to be considered is Avoidance, at least for particular sectors in the Malaysian economy.

Ethnic Tension and Ethnic Fractionalization appear in the top four for all three methods (see Table 4). The ultimate concern on this count is violence that might occur between Malays and Chinese should an election turn out the Malay party, the United Malays National Organization, which has ruled the country since its origin in 1957. In 1969, when it appeared that a close election might turn in favor of the opposition, inter-ethnic violence on a large scale led to intervention by the military and the suspension of democracy for two years. The economy was restructured to give preferable treatment to the Malays, a system which has, in turn fostered an atmosphere in which much of the corruption occurs.

The Ethnic Tension variable links to the issues of Religious Tension (ICRG) and Islamic Fundamentalism (Economist method), again with a concern about violence and more restrictive measures by the government. Insurance again is the suggested solution (Johnston \& Howell, 2013) with regard to this possibility, both with respect to physical damage and production stoppage.

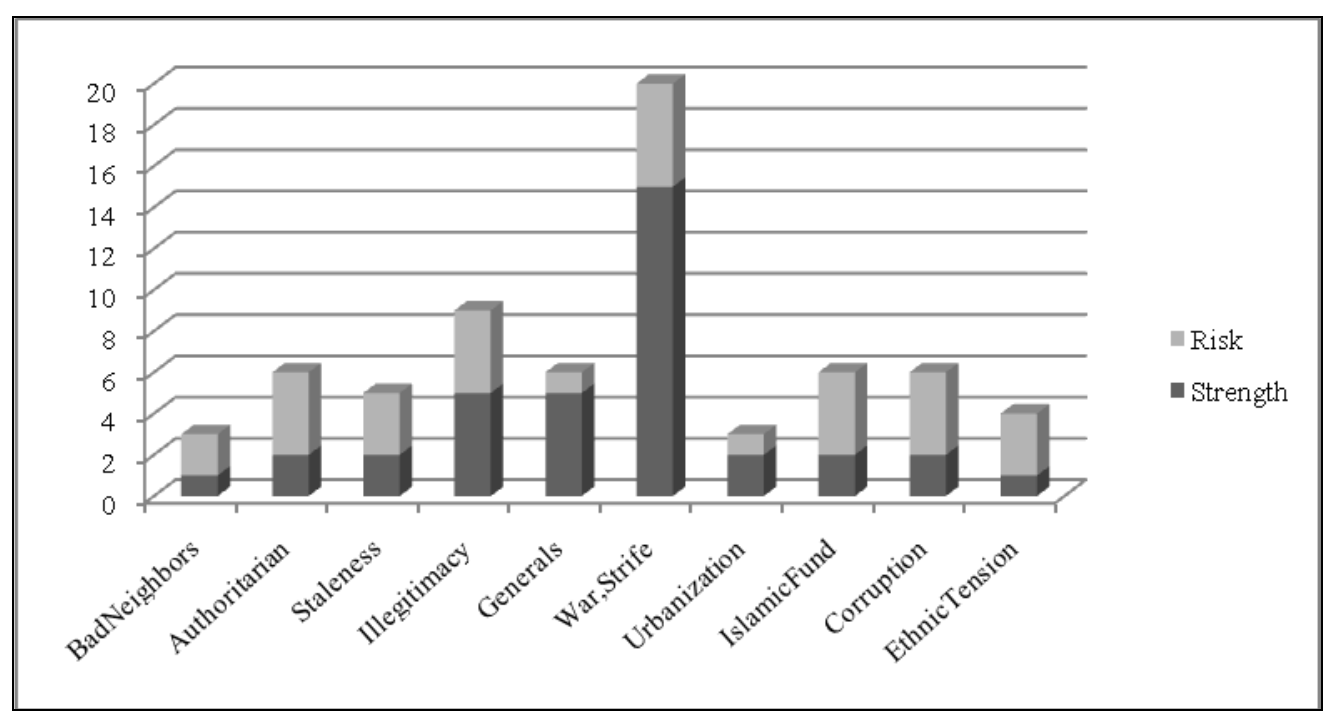

Figure 10. Present economist model March 2014.

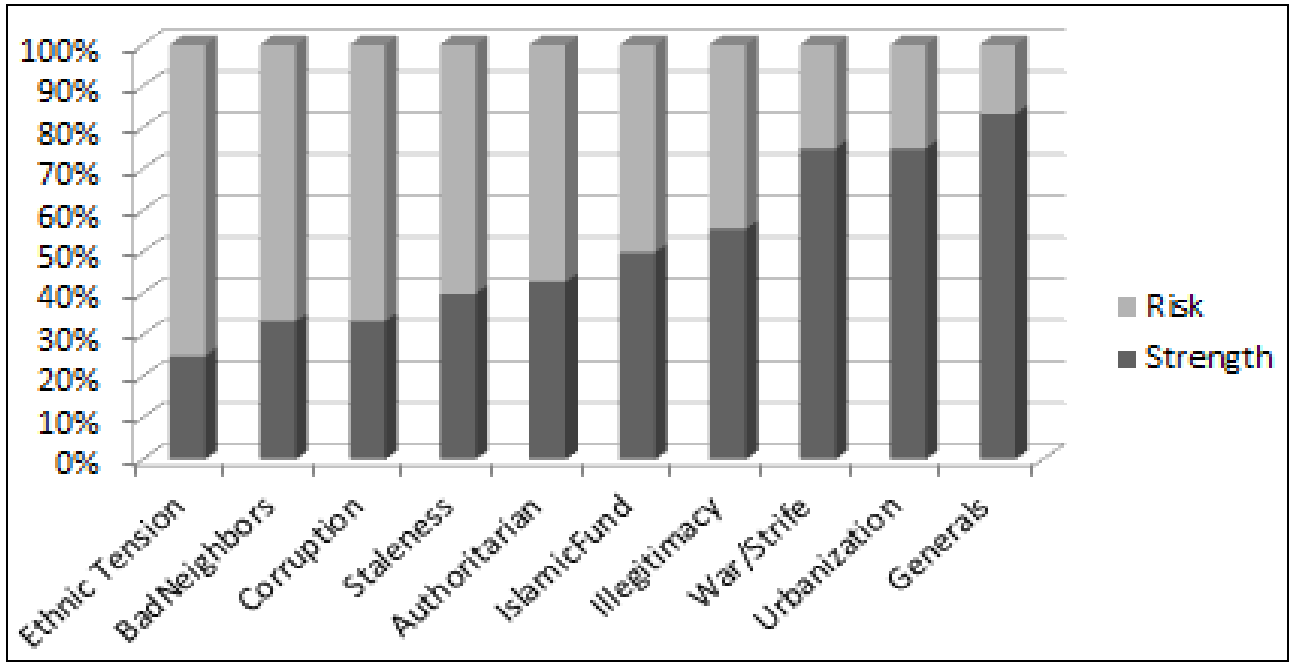

Figure 11. Present Economist model 2014 standardized and ordered. 


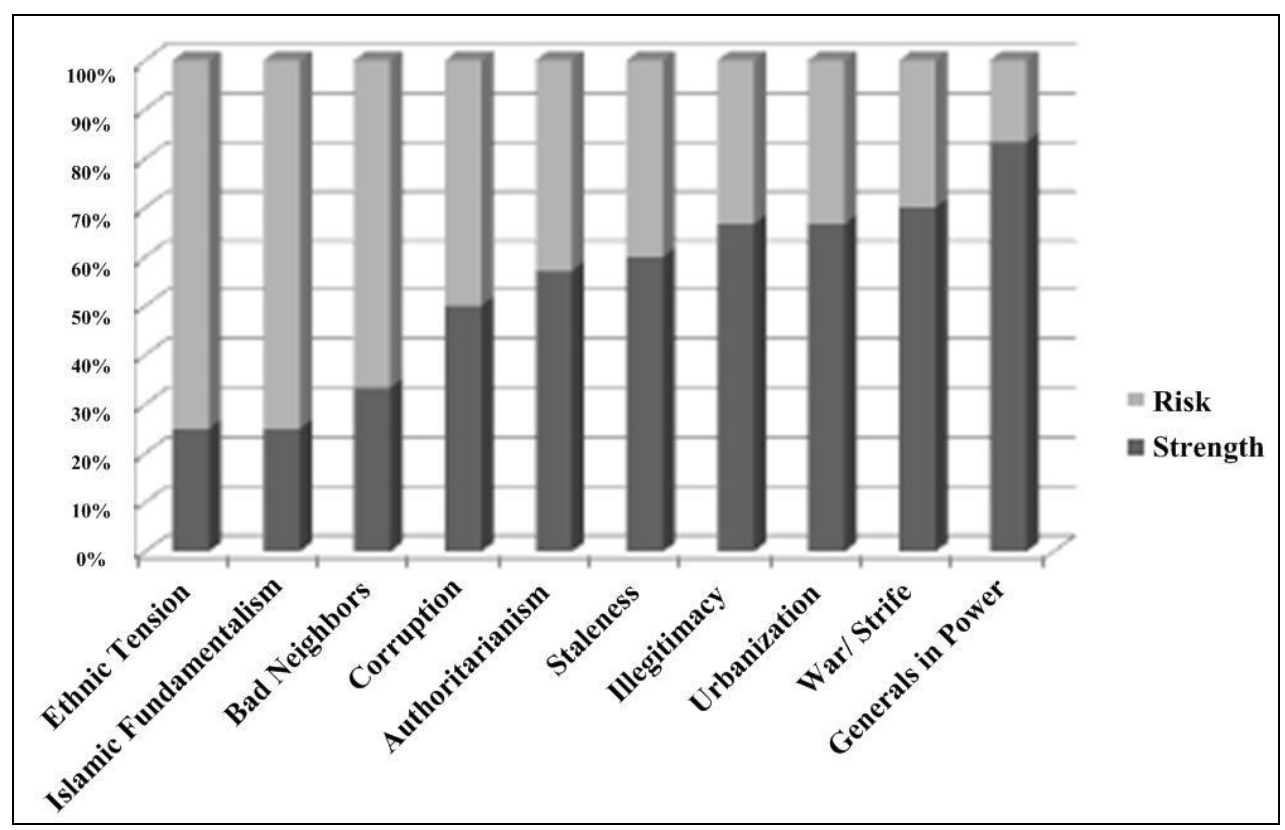

Figure 12. Malaysia five-year forecast economist model 2019.

With both BERI (Regional Political Forces) and the Economist method (Bad Neighbors or Proximity to a Trouble Spot or a Major Power) there should be concern given to the potentiality of military conflict in which Malaysia might be involved. Depending on the nature of the asset, especially, though, for oil and gas industries in the South China Sea, insurance against losses is a solution.

However one chooses to examine political risk in Malaysia, using the ICRG, BERI, or Economist methods (see Table 4), or some other means, each with its own analysts, some human element is involved directly in both assessing present conditions and in projecting those conditions and their impact out into the future. This is what experts do, in the true sense of that word. The identities of the ICRG and BERI experts are not provided to non-client users of the data. The identities of the 1986 experts for the Economist study are not known.

I've identified myself as the country specialist who provided the scores for the 2014 Economist study and something of the rationale used in assigning scores. The reader can disagree with any of us. But there are some commonalities in the three studies that strengthen the arguments about what a manager can and should do in approaching Malaysia with new investment. Corruption runs across the measures as the most significant problem. Ethnic and religious problems are clearly they are to be faced by the foreign investor, now mainly in human resource management, maybe later in more physical conflict. And then there is the encroachment by China, not just on territory but on resources, control of waterways, and control of territory an investment therein. In all, there is some danger here. Malaysia is such a seemingly calm and productive country that it initially allays political risk concerns but investors need to be cautious.

\section{References}

Allison, J. M. (1973). Ambassador from the prairie or Allison in Wonderland. Boston: Houghton Mifflin. Armstrong, K. (2000). The battle for god. New York: Ballantine Books. Clubb, O. E. (1962). The United States and the Sino-Soviet bloc in Southeast Asia. The Brookings Institution. Fuller, T. (2009, May 8). A Fracas in Malaysia makes instantaneous headlines. The New York Times, p. A10. Fuller, T. (2013, October 20). Wave of high-profile crimes has put Malaysians on the defensive. New York Times, p. A9. 
Goldman, J. (2006a, May 7). Estimate vs. reality: Logic, prediction, empiricism. At the Second Annual INTELCONF, Washington, DC.

Goldman, J. (2006b). Words of intelligence: A dictionary. Scarecrow Press.

Gooch, L. (2011, March 24). In Malaysia, Shiites struggle to practice their faith. The New York Times, p. A6.

Haner, F. T., \& Ewing, J. S. (1985). Country risk assessment: Theory and worldwide practice. New York: Praeger.

Hatipoglu, S. (2013). Business environment risk intelligence (BERI). In L. D. Howell (Ed.), The handbook of country and political risk analysis (pp. 123-154). East Syracuse, NY: The PRS Group.

Howell, L. D. (2006, May). Pirates: Scourge of the modern seas. USA Today Magazine, May 2006, 19-22.

Howell, L. D. (2013). Sea piracy as political risk. In L. D. Howell (Ed.), The handbook of country and political risk analysis (5th ed.) (pp. 365-374). East Syracuse, NY: The PRS Group.

Howell, L. D. (1986). Area specialists and expert data: The human factor in political risk analysis. In J. Rogers (Ed.), Global risk assessments: Issues, concepts \& applications Book 2 (pp. 47-84). Riverside, CA: Global Risk Assessments, Inc..

Howell, L. D. (1971). Building a Southeast Asian Identity: An assessment of attitudes of Filipino leaders. Southeast Asia Quarterly, 5(3-4), 1-11.

Howell, L. D. (1973a). Regional accommodation in Southeast Asia: A study of attitudinal compatibility and distance. Ph.D. Dissertation, Syracuse University.

Howell, L. D. (1973b). The Chinese in Southeast Asia: China commitments and local assimilation. Asian Studies, 14(3), 37-53.

Howell, L. D. (1974). Attitudinal distance in Southeast Asia: Social and political ingredients in integration. Southeast Asia, 3(1), 576-605.

Howell, L. D. (1973c). Regional accommodation in Southeast Asia: A study of attitudinal compatibility and distance. Ph.D. Dissertation, Syracuse University.

Howell, L. D. (1977). Compared attitudinal dimensions in Hawaii: A combined social distance-factor analytic approach. Ethnicity, 4(1), 1-18.

Howell, L. D., Carlos, C., Thumrongvit, R., \& Bock, J. G. (1984). The international attitudes of Southeast Asians: An evolutionary perspective. Southeast Review of Asian Studies, V, 63-77.

Howell, L. D. (1990). Elite attitudes and foreign policy: A study of the international perspectives of Malaysian civil servants. Annual Meeting of the Association for Asian Studies, Chicago.

Howell, L. D. (1993). Ethnic conflict threatens international stability. USA Today Magazine, 122(2578), 31;

Howell, L. D., \& Palmer, R. (1995). Malaysia: The anxieties of success. In Y. C. Kim (Ed.), The Southeast Asian economic miracle. Transaction Publishers.

Howell, L. D. (2002). At the end of the circle of pluralism. USA Today Magazine, 130(2682) (March), 63.

Howell, L. D. (2006). Ironies of illegal immigration. USA Today Magazine, 134(2734), 19.

Howell, L. D. (2010). Let me see your papers. USA Today Magazine, July, 139(2782), 31.

Howell, L. D. (2011). Losing the race to erase racism. USA Today Magazine, March, 139(2790), 62-65.

Howell, L. D. (2012a). Not Art! Forecasting political risk in a world of turmoil. Paper presented at the International Studies Association Annual Meeting, San Diego, CA, USA, April 3.

Howell, L. D. (2012b). TV Ads in black and light. USA Today Magazine, November, 58-60.

Howell, L. D. (2015). Victims of the night: What is racism in modern society? Paper presented at the Annual Meeting of the International Studies Association, New Orleans, LA, February 20.

Howell, L. D., Carlos, C., Thumrongvit, R., \& Bock, J. G. (1984). The international attitudes of Southeast Asians: An evolutionary perspective. Southeast Review of Asian Studies, V, 63-77.

Huntington, S. P. (1996). The clash of civilizations and the remaking of world order. New York: Simon \& Schuster.

Johnston, S. L., \& Howell, Llewellyn D. (2013). Political risk insurance: OPIC and other Insurers. In L.D. Howell (Ed.), The handbook of country and political risk analysis (pp. 377-406). East Syracuse, NY: The PRS Group.

Langewiesche, W. (2005). The outlaw sea: A world of freedom, chaos, and crime. Macmillan: Farrar, Straus and Giroux.

Luft, G., \& Korin, A. (2004). Terrorism goes to sea. Foreign Affairs, November.

Manji, I. (2003). The trouble with Islam. New York: St. Martin's Press.

McKee, C. (2013). International country risk guide (ICRG). In L. D. Howell (Ed.), The handbook of country and political risk analysis (pp. 41-122). East Syracuse, NY: The PRS Group, Inc..

O'Connell, J. (1997). Political risk insurance. In J. O'Connell (Ed.), The blackwell encyclopedic dictionary of international management (pp. 230-233). Cambridge, MA: Blackwell Publishers. 
PRS Group. (2004). A business guide to political risk for international decisions. East Syracuse, NY: The PRS Group, Inc.. Retrieved from http://www.PRSgroup.com

SAIS Conference Report. (2003). An expansion on this concern can be found in "Political Islam in Southeast Asia". Retrieved March 25, 2003, from http://www.sais-jhu.edu/programs/asia/sea/sea_publications/southeast_asia/political_islam_report.pdf Stern, J. (2004). Terror in the name of god: Why religious militants kill. Publisher: Harper Perennial.

Transparency International. (2013). Corruption perceptions index 2013. Retrieved from http://www.transparency.org Wolters, O. (1999). History, culture, and region in Southeast Asian Perspectives. Studies in Southeast Asia, 40(1), $147-150$. 